\title{
FOR A GENETIC AND DIPLOMATIC APPROACH TO OLD CADASTRES: PROPOSALS AND ADVICE FOR EDITING CADASTRAL SOURCES
}

\author{
EZÉCHIEL JeAN-COURRET \\ Université Bordeaux Montaigne \\ FRANCE
}

Date of receipt: $6^{\text {th }}$ of February, 2019

Date of acceptance: $3^{\text {rd }}$ of February, 2020

\section{Abstract}

Old cadastres are largely used as sources in a good many geohistorical publications. Although often reduced to their planimetric aspect alone, they form the kernel of a substantial documentary output. The constraints on the making of these documents (registers and maps), but also the constraints we place on them when using them for ends other than their initial fiscal purpose, must be highlighted so researchers can guard against making improper use of them. Cadastres form the basis of many geohistorical reference frameworks and must be subject to critical editing that is as thorough and true as historians' editing of texts. The specific features of cadastral sources as documents invite us, to do this, to take up and use the tools of diplomatics and text genetics and ultimately to suggest a few methodological pointers.

\section{KeYWORDS}

Old cadastre, Editing, Diplomatics, Text genetics, Geohistorical reference framework.

\section{Capitalia Verba}

Vetus catastrum, Editio, Diplomatia, Stemma codicum, Positio geohistorica. 
The term "cadastre" encompasses a very broad range of sources that have served since Antiquity as tools for assessing, apportioning, and levying taxes which, in the vast majority of cases, fell on land ownership. ${ }^{1}$ Reckonings, rolls, rosters, cadastres, Domesday book - to cite but a few types - make up something of a rag-bag of a corpus. These names evoke more or less complex composite records; inventories of individuals, spaces, and taxes forming registers for which the question of location meant that maps were first a helpful (although not mandatory or even auxiliary) representation, before becoming - through the power of the image and the new potential of their own resources- documents that superseded the written word. ${ }^{2}$ Among them, the cadastre promulgated by the finance act of 15 September 1807 and commonly called the "Napoleonic cadastre" or the "old cadastre" provides scholars with material that has been widely exploited further to Marc Bloch's invitation to do so. ${ }^{3}$ In France, ever since the pioneering work of the Besançon school, ${ }^{4}$ cadastres have continued to be a centre of interest for historians, archaeologists, morphologists, archaeogeographers, specialists of spatial and urban planning, and so forth. Over the last two decades, the emergence of research into the making and workings of space and landscape, together with the digital revolution -and in particular the revolution in the dissemination of digital mapmaking in the human sciences and the research challenges the Internet poses in critical cartography- 5 have been part of the near-exponential character of geohistorical publications ${ }^{6}$ in which the old cadastre is often a major data source. Now that it has lost its original

1. For the definition of the Napoleonic cadastre or old cadastre: Belmondi, Pierre. Code des contributions directes ou Recueil méthodique des lois, ordonnances, règlements, instructions et décisions sur cette matière. Paris: without publisher, 1818: I, 155; Josat, Jules. Le Ministère des Finances, son fonctionnement, suivi d'une étude sur l'organisation générale des autres ministères. Paris: Berger Levrault \& C ${ }^{\mathrm{ie}}$, 1883: 445-446; Tissier, Pierre. La Contribution foncière. Impôts d'État, Impositions locales, Alsace et Lorraine. Paris: Éditions Godde, 1928: I, 11. For a more institutional definition: Maurin, André. Le Cadastre en France: histoire et rénovation. Paris: Éditions CNRS, 1992: 13; by metonymy, cadastre also refers to the administration tasked with these operations. To these all too contemporary definitions of cadastre, I have preferred to target the common points of these fiscal and socio-economic documents that are arranged for convenience under cadastre as a generic type.

2. See on this the series of three colloquia: Rigaudière, Albert. De l'estime au cadastre en Europe: le Moyen Âge, colloque des 11,12 et 13 juin 2003. Paris: Comité pour l'histoire économique et financière de la France, 2006; Touzery, Mireille. De l'estime au cadastre en Europe: l'époque moderne, colloque des 4 et 5 décembre 2003. Paris: Comité pour l'histoire économique et financière de la France, 2007; Bourillon, Françoise; Clergeot, Pierre; Vivier, Nadine, dirs. De l'estime au cadastre en Europe: les systèmes cadastraux aux XIX $X^{e}$ et $X X^{e}$ siècles, colloque des 20 et 21 janvier 2005. Paris: Comité pour l'histoire économique et financière de la France, 2008.

3. Bloch, Marc. "Les plans parcellaires en France". Annales d'histoire économique et sociale, 1 (1929): 60-70 et 390-398; Bloch, Marc. "Les plans cadastraux d'Ancien Régime". Annales d'histoire économique et sociale, 3 (1943): 55-70. Remember, though, that Bloch's invitation to French historians was largely influenced by the German school and the works of August Meitzen (1822-1910).

4. Chouquer, Gérard; Favory, François; Baures, Pierre-Yves; Charraut, Daniel; Duvernoy, Jacques. Contribution à la recherche des cadastres antiques. Paris: Les Belles Lettres, 1980.

5. Joliveau, Thierry; Noucher, Matthieu; Roche, Stéphane. "La cartographie 2.0, vers une approche critique d'un nouveau régime cartographique", L'Information géographique, 77/4 (2013): 29-46.

6. Still only a tiny proportion of publications in social and economic history use cadastral matrices among all the publications in which the cadastre is implemented. 
fiscal purpose, the Napoleonic cadastre has found a new one: that of being a source of information through the regressive analysis and approach to the exploitation of its huge memorial potential. ${ }^{7}$

Yet many investigators use cadastres with infinitely less respect and precaution than they take when handling what they have raised to the rank of sources: texts, remains of buildings, ceramics, coins, etc. Although Henri Galinié alerted scholars to considering "space as a resource", ${ }^{8}$ it can only be observed that the spatial evidence recorded on cadastres is not quite there yet. This is because of two difficulties. The first is that when scholars hear "cadastre", they usually understand simply "map", missing out on the analysis of cadastral registers and instead using only what can be readily and immediately assimilated in their research: a piece of a figurative representation of space in which they perceive the trace of former occupancy. The second is that topology software (and more broadly still geographical information technology GIT) now makes it possible to do just about everything, at the risk of deforming the original source, which no-one would dream of doing when editing a text or compiling a corpus of archaeological material. My intention here is not to say what can and cannot be done when exploiting cadastres - their already substantial heuristic potential keeps on growing; my approach looks to take up a position ahead of the studies and analyses based on old cadastres, and therefore at the stage of their publication, by synthesizing the experiences of them, the problems met and the solutions adopted within the Atlas historique des villes de France collection, the early issues and more recent editions of which take the Napoleonic cadastre as their cartographical benchmark. ${ }^{9}$ Although cadastres and texts are not commensurable as

7. Abbé, Jean-Loup. “Le paysage peut-il être lu à rebours? Le paysage agraire médiéval et la méthode régressive", Les territoires du médiéviste, Benoît Cursente, Mireille Mousnier, dirs. Rennes: Presses universitaires de Rennes, 2005: 383-399. Maps preserve as traces (parcel map) or remains (built environment, highways) the memory of former developments of geographical space. The regressive analysis of maps and the identification of these traces provide data that are often not documented elsewhere; these approaches (morphology, archaeogeography) have extensively renewed the study of the spatio-temporal dynamics at work in the formation of ancient and contemporary landscapes. See also: Chouquer, Gérard. Les formes du paysage, 3 vols. Paris: Errance, 1996-1997; Chouquer, Gérard. L'étude des paysages. Essais sur leurs formes et leur histoire, Paris: Errance, 2000; Gauthiez, Bernard. Espace urbain. Vocabulaire et morphologie. Paris: Éditions du patrimoine, 2003: 233 (article "mémoire du parcellaire").

8. Galinié, Henri. Ville, espace urbain et archéologie. Tours: Université de Tours, collection Sciences de la Ville, 2000: 115: "If space is indeed paramount in apprehending the city archaeologically, it cannot be subject to partial questioning - It cannot be expected that the accumulation of partial answers can justify a dialectic between society and space- Therefore in our practice, setting ourselves the aim of understanding and explaining the working and the making of urban space involves giving urban space a particular status, that of a source and a subject of research".

9. Collection founded by Philippe Wolff and Charles Higounet in 1973 under the patronage of the International Commission for the History of Towns (ICHT). The first 49 volumes were edited by JeanBernard-Marquette; Sandrine Lavaud and I are currently the co-editors (Ausonius éditions). The reflections developed here have been impelled by the publication of the volume on Bordeaux (Lavaud, Sandrine; Jean-Courret, Ézéchiel, dirs. Atlas historique de Bordeaux. Bordeaux: Ausonius éditons, 2009: 49); some are set out in the specifications for the collection (on-line at: <http://ausoniuseditions.ubordeaux-montaigne.fr/images/AHVF_fr.pdf>; and in English at: <https://www.historiaurbium.org/wpcontent/uploads/2017/11/cahier_des_charges-Atlas-France-version-anglaise.pdf $>$ ); others have matured in recent years in the context of the regional programme "Les villes-têtes de l'Aquitaine: approches 
sources, it is possible to try to edit a cadastre with the same critical mindedness and critical method as when editing a text, by going back to the sciences of document publishing, in particular diplomatics dear to medievalists ${ }^{10}$ and text genetics dear to literary scholars. ${ }^{11}$ From this perspective, it is first necessary to target the intrinsic limits of the source through the multiple stages of its making. Once these constraints have been pointed up, some editorial proposals and advice shall be submitted, without omitting to discuss the constraints and limitations weighing on the digital handling of data.

\section{Documentary limits and constraints}

The constraints that the services involved in cadastral undertakings had to manage, the lifetime of old cadastres, and their updating all weigh on the available sources we consult in the present day. To identify the limitations inherent in the making of the documents and in their past use, we shall draw here on the specific case of the parcel cadastre initiated by the Gaudin Act (1807), which was completed for the whole country around 1850, through the examples of the small, mediumsized, and large agglomerations of Aquitaine that make up the primary theatre of the work I have been involved in for more than a decade. The limitations discussed below are far from being specific to this type of source and to this geographical area and may be identified in comparable sources of various periods and in other regions. ${ }^{12}$

historique, cartographique et comparative (2013-2018)" we directed and that led to the publication of five new volumes on Agen (Lavaud, Sandrine; Jean-Courret, Ézéchiel, dirs. Atlas historique d'Agen. Bordeaux: Ausonius éditons, 2017: 50), Pau (Bidot-Germat, Dominique; Devos, Cécile; Juliat, Christine; Jean-Courret, Ézéchiel, dirs. Atlas historique de Pau. Bordeaux: Ausonius éditons, 2017: 51), Montde-Marsan (Berdoy, Anne; Jean-Courret, Ézéchiel, dirs. Atlas historique de Mont-de-Marsan. Bordeaux: Ausonius éditons, 2018: 52), Périgueux (Gaillard, Hervé; Mousset, Hélène; Jean-Courret, Ézéchiel, dirs. Atlas historique de Périgueux. Bordeaux: Ausonius éditons, 2018: 53) et Bayonne (Boutoulle, Frédéric; Jean-Courret, Ézéchiel; Lavaud, Sandrine, dirs. Atlas historique de Bayonne. Bordeaux: Ausonius éditons, 2019: 54).

10. Bourgain, Pascale; Vielliard, Françoise, eds. Conseils pour l'édition des textes médiévaux. Paris: CTHSENC, 2001. Beyond medieval diplomatics and the critical edition of textual sources, many works in recent years by medievalists on written culture form a "renewed archaeology of the text" based on a critical exigency that examines texts and their material supports as the result of social production; the summary of these works and the epistemological reflections raised by Pierre Chastang (Chastang, Pierre. “L'archéologie du texte médiéval. Autour de travaux récents sur l'écrit au Moyen Âge", Annales HSS, 2 [2008]: 245-269) overlap with certain positions developed in this contribution.

11. De Biasi, Pierre-Marc. Génétique des textes. Paris: CNRS Éditions, 2011.

12. Abbé, Jean-Loup, dir. Estimes, compoix et cadastres: histoire d'un patrimoine commun de l'Europe méridionale. Toulouse: Le Pas d'oiseau, 2017. 


\subsection{Nature of the documentation and cadastral operations}

The great diversity of actors involved in drawing up the cadastre, the complexity of the operational process by which it was made, and the incredible wealth of the documentation produced are the most visible part studied by historians. ${ }^{13}$ But, when one looks only at the outcome of the operations - confining oneself more often than not to the maps alone- and when they are to be used for research purposes other than their initial objective, a series of problems and blind spots arises -or at any rate should catch the attention of those who wish to use the cadastres so they can exploit their full potential while respecting the integrity of the source. The production of a flowchart combining the actors, the stages of the process, and the types of documents produced (see illustration 1) makes it possible to identify the constraints the actors faced and the mistakes they made, which together form the limitations of the documentation. The documentation is extremely rich and ramified, with several tens of documents of different kinds concealed behind the semblance of the landscape as yielded up by the map. And while it is nowadays easy to have access to cadastral maps because of the general effort to digitize them and put them online on most local-authority archive websites, ${ }^{14}$ it is necessary to explore all the written records associated with the maps and the context in which they were drawn up in order to grasp the scope of the problems. The rich archival heritage of the cadastre cannot be reduced to the map alone; it includes a substantial number of sources which can be arranged into three main sets: ${ }^{15}$ first the "normative and regulatory documentation" governing the making of it; then the "constitutive documentation" formed by the map and the registers made for each commune ("district"); and lastly "ancillary documents gravitating around the first two categories" and that are so many markers and stages for understanding the making of the document.

The parcel-based cadastre marked a major reform in the history of land taxation that solved some of the problems with recovering each taxpayer's dues in a way the cadastre based on crop types could not readily do. It was underpinned by substantial normative documentation beginning with the legislation on its creation (1807), the transfer of responsibility for it to the départements (1821), and the empowerment of the départements to pass an annual tax to finance it (1829; see illustration 1, A). Within the département, the prefect, as the representative of central government, oversaw the operations entrusted to the administration of Direct Contributions

\footnotetext{
13. For an exhaustive bibliography: Grinevald, Pierre-Marie. Le cadastre. Guide des sources. Paris: Comité pour l'histoire économique et financière de la France, 2008 ( $3^{\text {rd }}$ extended edition); see also Bourillon, Françoise; Clergeot, Pierre; Vivier, Nadine, dirs. De l'estime au cadastre en Europe...

14. For France, see the census of old cadastre available on the Internet at: <https://sites.google.com/site/ histoireducadastre/les-cadastres-sur-internet>.

15. The typology by Laurent Perillat and Sébastien Savoy on the cadastral documentation of Savoy has largely contributed to this reflection; the terminology used here is borrowed directly from them (Périllat,

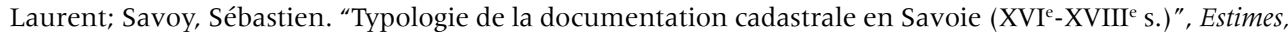
compoix et cadastres: histoire d'un patrimoine commun de l'Europe méridionale, Jean-Loup Abbé, dir. Toulouse: Le Pas d'oiseau, 2017: 240-263, esp. 248-251).
} 
placed under the supervision of the Finance Ministry. The prefects, in conjunction with the local councils (Département, Arrondissements, Cantons) put in place an operational strategy by choosing the cantons and communes to be included in the cadastre (see illustration 1, B). The minutes of the meetings of the local councils recorded the decisions concerning these procedures: where these have not been preserved, the local authority statistical yearbooks provide a good idea of the timing of operations. Besides, compendia regulated the two major operations involved in the making of the register, namely the operations in the field, which made up the "survey work"16 (boundary marking, topographic surveys, draughtsmanship and graphic symbols) and the administrative operations which encompassed the assessment of land for its taxation and that formed the "land valuation". ${ }^{17}$ The director of Direct Contributions coordinated all of the services responsible for the work on the scale of the département and of the commune included in the cadastre. These different tasks were highly interdependent; for the sake of clarity they are set out below by type, regardless of their actual timing which overlapped in part and might even be reversed depending on the cases under study.

\subsection{Field operations}

The survey work was orchestrated by a chief surveyor. The staff he directed comprised a triangulation surveyor, a boundary surveyor, and several teams of topographical surveyors. The organization chart was fully adapted to the order of operations with each step inheriting constraints and being subject to error. The triangulation surveyor was tasked with producing a triangulation canvas on the scale of the département which he then refined for the commune (see illustration 1, 1). That is, he chose and precisely fixed the position of a system of points by defining triangles each summit of which enabled trigonometric calculations to be made for all the land surveying work. This decisive stage was very much dependent on the local topography where excessively steep or, on the contrary, excessively flat relief might inhibit the formation of a suitable canvas. In the Landes, the surveyor Calan was unfairly vilified by the Director of Contributions and the Minister of Finance for failing to comply with the "essential art of triangulation", but in doing so they disregarded the obvious flatness of the relief in the Landes and the sparse density of

\footnotetext{
16. Pommiès, Michel; Reynaud, Antoine André Louis. Manuel de l'ingénieur du Cadastre, Par Mr Pommiès, Professeur au Lycée Napoléon, Examinateur des Ingénieurs du Cadastre, Membre de l'Athénée des Arts; Précédé d'un Traité de trigonométrie rectiligne, par. A. A. L. Reynaud, Répétiteur d'Analyse à l'École polytechnique, Professeur des élèves du Cadastre; et des Instructions publiées pour l'exécution des Arpentages parcellaires, approuvées par la Ministre des Finances. Paris: Imprimerie impériale, 1808; Busset, Crispin-Fanfan. Traité pratique de la partie d'art $d u$ cadastre. Clermont-Ferrand: L'Imprimerie de Thibaud-Landriot, 1827; see on these works: Baptiste, Gérard. “Les signes conventionnels et les modes de représentation du plan cadastral Napoléonien. Le cadastre 'Napoléonien', instrument de la recherche historique et archéologique". Revue XYZ, 27 (1986): 1-10; on-line at <http://sites.google.com/site/histoireducadastre/ressources>.

17. Hennet, Albert Joseph, Recueil méthodique des lois, décrets, instructions et décisions sur le cadastre de la France. Paris: Imprimerie royale, 181 1; Belmondi, Pierre. Code des contributions directes...
} 
settlement which meant there were not enough vantage points for the survey. ${ }^{18}$ In Périgueux, conversely, where the relief was conducive to this stage of the process, it was a mistaken calculation for a triangulation point that meant the superintendent, Lefèvre, would only certify the cadastral plans of 1828 once the corrections had been made. ${ }^{19}$ Among the many items in the ancillary documentation, researchers should consult the triangulation reports and maps, the verification reports and tables, and the trigonometric rectifications because they can explain many of the concerns that arise when georeferencing the maps (see below).

In parallel to the formation of this canvas, the bounds of the commune were delimited by the boundary surveyor (see illustration 1,2). Operating in just the same way as for the medieval montrée, by visiting the locations so as to determine their bounds, the boundary surveyor, the mayor of the commune to be surveyed for the cadastre, and the mayors of the adjoining communes walked the boundary and drew up a boundary deed that was often accompanied by sketch maps. This stage predetermined the topographical survey work but also ensured the fair apportionment of the contribution each taxpayer was to bear. ${ }^{20}$ This delimitation, which seems self-evident to us nowadays, might last several days, or even months, and in some instances even years because it rekindled sometimes centuries-old land disputes, requiring a precise delimitation of boundaries that were not always sharp dividing lines, or provided an opportunity to display a healthy appetite for land-grabbing by a town looking to encroach on all the communes over which its urban footprint extended. No ville-tête in Aquitaine (Agen, Bayonne, Bordeaux, Mont-de-Marsan, Pau, Périgueux) escaped these tensions which often delayed the certification of the cadastres and the collection of taxes. The problems were no less sizeable for the market towns of the rural communes, as the study of the communes within the jurisdiction of Saint-Emilion evokes. ${ }^{21}$

Once the bounds of the commune had been established, the surveyors had to delimit the sections ${ }^{22}$ and localities (see illustration 1,3) according to their settlement density. This operation had an impact on the scale of the maps (1:2500 for rural

18. Jean-Courret, Ézéchiel. “Mont-de-Marsan vers la fin du Premier Empire. Édition du plan cadastral et analyse morphologique", Atlas historique de Mont-de-Marsan, Anne Berdoy, Ézéchiel Jean-Courret, dirs. Bordeaux: Ausonius éditons, 2018: 24.

19. Jean-Courret, Ézéchiel. "Périgueux vers 1830. Édition du plan cadastral et analyse morphologique", Atlas historique de Périgueux, Hervé Gaillard, Hélène Mousset, Ézéchiel Jean-Courret, dirs. Bordeaux: Ausonius éditons, 2018: I, 34.

20. For example in Périgueux and Champcevinel some taxpayers were taxed double because the mayors failed to agree on the boundaries of their respective communes.

21. Jean-Courret, Ézéchiel. “Le plan de la juridiction de Saint-Emilion vers 1814-1845: édition des plans cadastraux", Saint-Emilion et sa juridiction. Genèse, architectures et formes d'un territoire, Frédéric Boutoulle, ed. Bordeaux: PCR DRAC-SRA Aquitaine. Bordeaux, 2011-2013 (report 2011).

22. Maurin, André. Le Cadastre en France...: 229: "the section is a portion of the territory of the commune comprising a whole number of localities whose perimeter is made up, as far as possible, by natural boundaries — communication routes, water courses - or is of a sufficiently fixed character" (e.g. an outstanding alignment of parcel boundaries). 
areas; 1:1250 to 1:500 for dense and very dense urban areas ${ }^{23}$ ) and the number of sheets composing the section (one or more sheets of grand aigle format). This work required a thorough field enquiry involving the inhabitants during which all of the place names were collected (names of hills and mountains, water courses, roads and paths, minor place names). I have found no trace of these enquiries although they are the reference material for all the names recorded on the fair drawings, names that form the "lettering" of the map. There arises here the question of the spelling used by the surveyors to transcribe the verbal declarations of the inhabitants, not forgetting the difficulties that surveyors who were not necessarily from the area must have met with the vernacular idioms that were very much entrenched in communities of the first half of the nineteenth century. Besides, the names as transcribed on the maps often vary, at least in their spelling, from the place names (lieux-dits, "places said") recorded in the tables of the cadastral registers, these place names having been collected by others at the time of the land valuation (see below). It seems important to me therefore not to seek to unify the spelling of these names in the context of editing work, or to replace them by the present-day names, insofar as these variants - although a hindrance for managing the data bases- may provide valuable clues for regressive historical approaches.

The surveying work by the team of first- and second-class surveyors was conducted on the parcel scale; this elementary unit of ownership was identified by a number attributed within each section; the number marked on the map serves as a cross-reference to the information listed in the cadastral registers. More often than not only the overall result of the survey is known, that of the map, which provides a comprehensive, careful, and precise representation of land occupancy, the distribution of built and non-built property without any representation of the relief. The operation depended in large part, though, on the degree of accuracy of the surveying tools used (theodolite, surveying compass and chain, alidade, etc.), on the simplicity or complexity of the building, or the shape of the plot depending on the topography, and lastly, on the drawing instruments and skills of the surveyors who kept the field books from which the maps were drawn up. These working records have rarely been preserved and those which have been often appear more detailed than the fairdrawn maps but still remain comparatively varied in the application of the rules of signs and symbols. ${ }^{24}$ They also come with notebooks of calculations of the areas of each parcel, differentiating built and non-built areas, which was essential information for the apportionment and final computation of taxes but which might also be subject to many computational mistakes.

The difficulties encountered by surveyors could often affect the whole of a sheet or a section, when the problem was one of triangulation, but more often than not, the trouble concerned only particular buildings - obviously not simple four-sided units, but more complex buildings and often public edifices or edifices for public

23. After 1837, this unwieldy set of scales was replaced by 1:2000 for rural areas and 1:1000 for areas of clustered settlement and developments.

24. Baptiste, Gérard. "Les signes conventionnels...". 
use. This was the case for example with the château of Pau, which looks like a formless mass on the 1812 cadastre (see illustration 2a) whereas the archaeological surveys or other plans of the time meant its outline could be very precisely traced (see illustration 2b). In any event, this example, which could be multiplied ad nauseam, should draw users attention to the degree of trust that can be placed in such mapping.

\subsection{The administrative operations}

The commune and the taxpayers could only comply with the cadastral operations. Their role was largely passive with respect to the surveying operations, except for the adversarial scrutiny of the bounds of the commune that involved the mayor and the granting of access to land that each proprietor had to ensure. They were, however, more manifestly involved in decision-making when it came to land valuation. The Contributions Office assessed land holdings by putting together a team headed by an inspector and made up of several landowners in the commune who were called on to officiate as owner-assessors, appointed by the municipal council. This arrangement meant the Contributions Office benefitted from the knowledge of people familiar with the geography of the commune and it was also a guarantee of support for the levy. The valuation procedures began if not at the start of the surveying work then shortly after it had got underway. They consisted in drawing up land types, land classes, and rentcharges (see illustration 1,5 ) so that properties could be taxed (see illustration 1, 6). The first of these two steps had a major impact on the cadastral documentation that was produced. The inspector and owner-assessors did not have as their objective to accurately depict the actual landscape of the commune, the categorization of lands was a simplifying operation - a generalization geographers would say - that did not specify the exact nature of every property but classified properties sharing common characteristics under the same general name. The division between built and non-built land was the first of these distinctions. The type of built property did not identify the true nature of private dwellings, for example, a hovel, a house, a mansion, or a tenement made up of several lodgings were all put down as "houses"; a barn, a hen house, or a cowshed were all included under "rural buildings". Similarly, for non-built property, fields of crops all appeared under the heading of "arable land", regardless of what the crops rotated actually were. This generalization of reality explains why the cadastre did not represent the true landscape; like any representation it was an interpretation of reality for precise purposes and exhibited only the chargeable or fiscal landscape. For the rest, so as to take account of actual differences in value between properties of the same type, the owner-assessors and the inspector identified different classes among them, usually three or four in number. Accordingly, the "land" classes differentiated among highyielding agricultural land in the loamy lowlands (class 1), and others with medium (class 2) to low yields (class 3) that enjoyed less favourable soil conditions. The rentcharges for each type of property and each class were evaluated on the scale of 
the département, by selecting communes that were supposedly representative of the advantages and drawbacks of the lands of the community. It was on the basis of this provisional rating, that was widely discussed so as to be adapted to the specific conditions of each commune, that the tax was ultimately calculated by combining data relative to land types and classes and the surface area of the parcels.

Before these final stages, the assessors used these various rentcharges to make the actual classification of all the properties within the constituency of the commune by going out on to the ground. The enquiry was lengthy (on average two to three years for the towns studied in Aquitaine) and systematically extended beyond the end of the surveying operations. It was the subject of plentiful discussions between the taxpayer - eager to pay, if not the fair amount, often the least possible! — and the valuation commission. It could be the opportunity to deform reality during the valuation process by type and class and for which the historian unfortunately cannot gauge the sincerity of those making the returns and of the assessors. Once completed, the classification tables served as a reference for the summary records (bulletins) drawn up for each parcel in the commune (see illustration 1, 7). These records were then deposited at the town hall for public consultation for a fortnight or so. Each landowner could come and inspect them, and at the same time examine the field records so they could make their complaints or, failing that, give their assent. Traces of complaints are seldom found and when they are they are few in number. This observation suggests not that the work was perfect in all particulars but that most problems were solved at the stage of the classification operation and of operations in the field, changing this consultative procedure into a stage of validation of the operations by ratification of the rentcharges.

Alongside this, the central administration could appoint a special superintendent to examine the surveying work. These superintendents did not intervene for all the communes included in the cadastre but just for the few communes in the département chosen jointly with the prefect and the director of Contributions. Often the main town of the département did not escape this supervision which was the source of valuable reports of inspections and corrections to be made (see above).

\subsection{Compilation and future use of documentation making up the cadastre}

The final stages before the collection of $\operatorname{taxes}^{25}$ were the compilation of the documentation making up the plans and registers forming the cadastre and their ratification. Using the field records, the surveyors produced in their offices the fairdrawn map made up of the various sheets of each section for which the figurative rules were harmonized (see illustration 1,8). The fairdrawn map was also used to validate the surveying procedure: it included a grid determined by

25. During the cadastral operations, land taxes were levied on the basis of the old matrices of the rolls. So here we refer only to the collection of land taxes as renewed by the introduction of the cadastre. 
the meridians and the perpendicular check lines of distances and surface areas of the parcels established from vantage points and various verification lines drawn from triangulation points. The arrangement of boundaries by sections and sheets was recorded on what was named a grid chart, drawn up on a small scale (often from 1:20,000 to 1:10,000) and providing the division of the territory and its main topographic characteristics (roadways, hydrography, general relief) so that users might identify the place of interest to them. Alongside this, the Contributions Office finalized two types of register: the cadastral matrix, "a document of a personal character recapitulating, by proprietor, the information concerning the built and non-built property he possessed in the commune", ${ }^{26}$ and the section statement, which recorded by section and parcel numbers the name - and sometimes the occupation - of the owner, the place name, the type of property, the class relating to each type of property, the surface area of the parcel and the income (amount of tax). ${ }^{27}$ The fairdrawn map and registers were subject to general ratification (see illustration 1, 9) and certification by the prefect and the director of Contributions, a procedure that guaranteed the implementation of tax collection..$^{28}$ On the basis of these exemplars — which the local-authority archives inherited — the Cadastre and Contributions Offices made at least one copy (sometimes even two working copies; see illustration 1, 9) intended for the town hall and kept in the communal archives, when these were not deposited with the departmental archives where they are also often found. The copying operation entailed a substantial loss of information - the copy of the map being by definition less precise than the fairdrawn map- and could also be the source of errors as concerned the registers. It is easy then to identify the exemplars still preserved: the fairdrawn map exhibits verification lines which the working copy of the map does not (see illustration 3); the registers copied are not generally signed by the authorities responsible for the operations (see illustration 4).

Lastly, the documentation making up the old cadastre served; its useful life was several decades and it was often updated as properties changed both in terms of size (dividing up, rearrangement of parcels) and type as well as in terms of ownership. The cadastral registers of some communes sometimes took account of these questions directly, involving additions, crossings-out, and other forms of correction (see illustration 5); other communes used "registers of increase and decrease" specially compiled by the administration to record such changes without alteration of the matrices and section statements. The same was the case for the maps on which new boundaries were marked to indicate new parcel divisions (see illustration 6a), or were scratched out on the document when on the contrary parcels were merged

26. Maurin, André. Le Cadastre en France...: 231: "It enables each taxpayer to ascertain the bases of the tax they owe."

27. The forms in these registers vary in their presentation and sometimes even their headings; here only the most widespread classificatory entries are presented.

28. Maurin, André. Le Cadastre en France...: 36-50. Remember that the old cadastre was for fiscal purposes only and had no legal dimension. This problem was compounded by the valuations being unequal and fixed and the map being unchangeable. This prompted revisions and renewals of the cadastre in several stages as from 1840 . 
(see illustration 6b). Maps were often modified in ways that largely exceeded the implementation of a new cadastre, serving as base maps for the projection of new spatial developments (new roadways can often be identified superimposed over the background of parcels; see illustration $6 \mathrm{c}$ ); this was not the case of registers for which corrections were discontinued whenever the cadastre was renewed. These multiple uses, but also the conditions of preservation (packaging of maps and registers, storage, harmful effects of careless users, relative humidity and temperature, parasites, etc.) have taken their toll on the documents that have come down to us and their effects must absolutely be identified from an editorial perspective because they necessarily imply that choices be made.

\section{Proposals and advice for editing cadastral sources}

The volumes of the Atlas historique des villes de France are meant to explain the processes involved in the making of towns and long-term spatial practices, from the origins of an agglomeration to the near present-day stages of its working. This perspective is based on the formation of a geohistorical frame of reference established from the old cadastre. Because every source is first a construction, it is necessary to set out the choices made and the limits of the manipulations we subject them to, because these operations are not neutral. The aim here is not to hide the possibilities but to bring them out into the open so that each delivers up its operating process. ${ }^{29}$

\subsection{Epistemological reflections}

My relations with the mapmaking disciplines have led me little by little to critically examine documentary sources in themselves as much as the attitude of researchers with respect to their planimetric output. For having handled old plans on a daily basis and for having produced my own maps, the heuristic field of representations, their study, their editing, and the explanation of all that they leave unspoken have become guidelines structuring my research and so much so that it is no longer possible to neglect the ties between cartographical sources and practices. While one may regret from the outset the lack of discussion between historians of cartography on the one side and on the other side historians and archaeologists who, among many others, use and produce maps —and often even have them made-, it is because their spatial angle of approach summons up the old disciplinary divides between geography and history, that geohistory has not managed to fill. ${ }^{30}$ This epistemological break is that much starker because often those who make maps are

29. Costa, Laurent. "La construction de référentiels géohistoriques: un enjeu pour l'interdisciplinarité dans les sciences historiques". L'Espace géographique, 41 /4 (2012): 340-351.

30. Chouquer, Gérard; Watteaux, Magalie. L'archéologie des disciplines géohistoriques. Paris: Errance, 2013. 
not entitled to their say, being confined instead to their positions as technicians in the "ancillary" domains of the sovereign disciplines.

Now, anyone who handles cadastral documentation in order to produce new frames of reference, cannot but observe that there are several versions of one and the same document, that crossings-out suggest corrective processes whereas deliberate overwriting or erasures attest to the length of time for which the documents have been used. But when it comes down to it, researchers must pick and choose among the information they wish to use: on the strength of what objective and reasoned criteria and with what tools? These two questions are closely interconnected but, where editing is concerned, computer processing of a text raises different difficulties to those arising with maps. Admittedly everyone knows in their scholarly entourage epigraphists or palaeographists who are concerned about encoding texts or typographic fonts. Once these questions have been settled, it can be conceded, though, that computerized editing (XML, TEI) imposes an acceptable number of constraints on the "original" text, quite simply because texts are by nature word groups of meaning. This is not true of maps, which, save for the lettering, require the meaning of their figurative symbols to be interpreted. But, while text editors provide readers with a critical apparatus justifying their choices in the handling of sources, few edited maps offer any such instruments. In these domains, apart from the pioneering case of the Tours school ${ }^{31}$ and the exemplary works of ANR ALPAGE, , $^{2}$ there is, to the best of my knowledge, no international standard, and the specifications of the French atlases still stand out as an exception in the broad international panel of atlases.

The wealth of evidence of the documentation making up the cadastre and appended to it, and the length of time over which these sources were drawn up and used imply a capacity to account for the choices made when selecting the maps and registers and when critically editing them. To that end, my education and training led me back to the disciplines of diplomatics and text genetics, responding in some sense to the wishes of the specialists of these disciplines who observe their epistemological malleability and their potential for transposition to new areas

\footnotetext{
31. The Totopi GIS compiles several cadastres of different periods. The computerization of Napoleonic cadastres for spatial and morphological analysis complies with quite precise specifications (Ben Nejma, Faycal. Le cadastre ancien de Tours: étude de morphologie urbaine. Tours: Université de Tours [Master Dissertation], 1992; Galinié, Henri; Chouquer, Gérard; Rodier, Xavier; Chareille, Pascal. “Téotolon, doyen de Saint-Martin, évêque de Tours et au X $\mathrm{X}^{\mathrm{e}}$ siècle et urbaniste ?", Village et ville au Moyen Âge: les dynamique morphologiques, Bernard Gauthiez, Élisabeth Zadora-Rio, Henri Galinié, dirs. Tours: Presses universitaires François-Rabelais, 2003: I, 239-256; II, 202-219).

32. Noizet, Hélène; Bove, Boris; Costa, Laurent, dirs. Paris de parcelles en pixels. Analyse géomatique de l'espace parisien médiéval et moderne. Paris: Presses universitaires de Vincennes, Comité d'histoire de la Ville de Paris, 2013. ALPAGE (AnaLyse diachronique de l'espace urbain PArisien: approche GEomatique) is a geohistorical information platform about Paris <http://alpage.huma-num.fr>; the geographical framework of the project is delimited by the "enceinte des Fermiers généraux" built in 1782 and demolished in 1860, covering 3370 ha. The planimetric reference frame selected comprises 910 city block plans by P. Vasserot drawn between 1810 and 1836, that is, before Haussmann's transformations.
} 
of study. ${ }^{33}$ At first sight, diplomatics, as the study of the transmission, form, and drawing up of deeds might seem very far removed from cadastres; but it proves to be an ideally adapted tool for their analysis insofar as the cadastre, as the sum of maps and registers, arises out of "practice" that offers several points of comparison with a legal action as instrumented by a charter. First because each cadastral undertaking arose out of official regulatory instructions; then because the agents of the Direct Contributions Offices were sworn personnel ensuring the performance of operations; and lastly because the documents produced included signs of validation that were formally marked on the maps via their title cartouches (see illustration 7), and on the registers (see illustration 8 )..$^{34}$

The title cartouche, ornamented in a manner specific to each author, was not a mere feature for decoration or for the legend ("what is to be read"); like a validation sign, it marked the document as authentic and true. It was formulated to provide a brief summary of the "operative part" of the deed and indicated all the authors responsible for the legal action (prefect, director of Direct Contributions, and chief surveyor), the authors of the map and its lettering (field surveyors), and the beneficiaries of the deed (the commune and by extension the population it represented and especially the landowners). In the section statement, the diplomatic character was particularly manifest because the printed form certified the authenticity of the cadastral undertaking (see illustration 8). The summary page closing each section indicated the areas of the taxable (parcels) and non taxable (highways, water courses, communal property) holdings, but above all it ended with a formal notice serving to certify the accuracy and conformity of the computations. For Saint-Emilion, each corps validated its area of expertise by signing off: the survey work of the map and the computation of the parcels were certified by the surveyor on 31 August 1846; his work was double-checked by an inspector of the cadastre and by nine ownerclassifiers, who signed off on 30 April 1847, before the validation procedure ended on 14 November 1847 by the signature of the director of Contributions, who was responsible for the fiscal assessment of the holdings, which was therefore done two years after the survey had been conducted (1845).

However, in examining the duration of the process of drawing up and validating cadastres of any particular commune, one realizes the limitations of diplomatics, which are more usually reserved for short time spans and for a precisely dated legal action. Moreover, while diplomatics is suitable for providing an internal

33. Guyotjeannin, Olivier. "La diplomatique médiévale et l'élargissement de son champ", Gazette des archives, 172 (1996): 17: "To dream of the diplomatic approach being extended in space and time is not the least enticing of projects. Even so, such a project would have to distinguish between what can be exported as it stands and what can no longer be, in view of the place writing has in any given society". De Biasi, Pierre-Marc. Génétique des textes...: 8: "As to the 'rhizomatous' complexity of the writing process that is so difficult to reconstruct in a book, it soon found means to match it in computer resources; genetics spontaneously attuned itself to the potential of the new tools of digital technology...".

34. Hennet, Albert Joseph. Recueil méthodique des lois...: 80 (art. 240); Baptiste, Gérard. "Les signes conventionnels...": 4: "the grid chart title must include indications of the commune, département, arrondissement and canton of which it was part, the names of the chief surveyor (or superintendent engineer), the field surveyor, and mayor of the commune." 
analysis of each item of the constituent documentation, there is a risk of distorting the approach by applying it generally to a dossier the inseparable items of which (map and registers) must necessarily be illuminated by other records (normative and ancillary documentation). For this the related disciplines of text genetics must be called on to avoid this pitfall and to complete the editing work.

Studies of literary genetics developed over the last thirty years by philologists share common features with diplomatics and in particular the features of critical analysis of manuscripts. They differ from it in that they shift thinking about the text towards the writing of it, from the completed work to its genesis instead, by looking into the processes of development of the document, the time span, the historical density of the written word more than the finished work. The genetic approach can therefore supplement the diplomatic approach by extending the enquiry to the external components that illuminate the stages in the making of the cadastre but also because the genetic approach is part of an editing approach (producing a geohistorical frame of reference) of what was until then a handwritten work (cadastral sources). The genetic stages in the writing process (pre-drafting enquiry, drafting stage, pre-editorial stage, and editorial stage) correspond to the stages in the editing of a cadastre (archival enquiry and data acquisition, structuring and recording of data, data validation, publication). The complementary character of the approaches must entail broader reflection leading to the establishment of cadastral diplomatics and genetics by which to transform the work of surveyors and administrative agents of the Direct Contributions, which remained at the stage of handwritten validation, into the digital and printed versions of a critical edition.

\subsection{Choosing the exemplars of use for editing}

Producing a geohistorical frame of reference by editing an old cadastre involves selecting the exemplars that can be used for the editing process, evaluating the problems and limits that these sources pose, and choosing the applications and protocols for georeferencing, vectorization, and metadata entry. We shall deal first with questions of the choice of sources before discussing the editing protocol (see below).

The understanding of the chronology, the persons involved, and the actions conducted during a cadastral campaign entail a thorough search of the archives for documents that are scattered across various collections. Although this stage is not a condition sine qua non of the editing project, it seems to me that it is the only stage at which a cadastre can be suitably contextualized, the reception of its operations by local authorities and taxpayers appraised, and the quality of the work conducted evaluated. At the very least, the editing project must articulate the map and the information recorded in the associated registers. To this end, the choice should fall on complete exemplars of the original fairdrawn maps and registers in preference to copies made from them. Depending on the objective of the research project, one may choose just one of the two types of register because the information in 
them is of the same nature but arranged in different ways: the section statement, arranged by section and parcel number, is easier to use in the context of geohistorical research; the matrices arranged by proprietors break down the information in a way that is more conducive to socio-economic studies. When the geographical areas under study extend beyond the boundaries of the commune, it must be checked that the documentation selected for the different communes covers the same dates, which cannot always be easily associated with the previous criteria. Thus, for Agen, an understanding of the urban site involves encompassing the whole floodplain of the River Garonne overlooked by the hill slopes of L'Ermitage and that includes the communes of Agen, Saint-Cyr, Foulayronnes, Boé, Bon-Encontre, and Le Passage. The major errors in the survey work of the cadastre of the commune of Agen of 18091812 (inaccurate survey of public buildings) prompted us to exclude this source although complete, and to select instead the revised cadastre of 1845; as we did not have a cadastre of the same date for the commune of Le Passage, which forms the left bank of the River Garonne opposite the town, we were compelled to select the 1809 cadastre. Accordingly the base map of the atlas formed ultimately just a picture of the Agen site in the first half of the nineteenth century. ${ }^{35}$ Sometimes, too, it is the state of preservation that weighs most heavily on the choice to be made and prompts the selection of a copy in better condition than a tattered fairdrawn map, as was the case in part for the work on Périgueux. Lastly garrison towns are a quite specific case. Military land (citadels, urban fortifications) are not usually included in the cadastre, pursuant to regulations published in 1811 on the cadastre of France. ${ }^{36}$ This is the case of the cadastre of Bayonne surveyed in 1831 and for which we had to reconstruct the missing part of the information by choosing a map of a similar date (1826) drawn up by the Engineering Corps. ${ }^{37}$

Beyond the old cadastre, the editor's choice must also cover georeferenced vector maps corresponding to the present day parcels and built areas because these data form the spatial frame of reference on which to "align" the old map within a presentday system of coordinates. The IGN's land parcel database (BD Parcellaire) and the digital maps produced by urban planning agencies or by mapping companies under contract with the local authorities are all examples of these land parcel maps which are considered the most reliable to date in a digital format, but the accuracy of which is difficult to evaluate. Lastly, the aligning of the old cadastre may sometimes be supported by other maps from intermediate periods - between the date of the current digital cadastre and that of the selected cadastral map- so as to palliate any

35. Jean-Courret, Ézéchiel. “Agen vers le milieu du XIX ${ }^{\mathrm{e}}$ siècle. Édition du plan cadastral et analyse morphologique", Atlas historique d'Agen, Sandrine Lavaud, Ézéchiel Jean-Courret, dirs. Bordeaux: Ausonius éditons, 2017: 18-20.

36. Hennet, A. J. U., Recueil méthodique des lois..., 54 (title IV, section I, chapter VIII, “Détails des plans”, art. 150): “He [the surveyor] confines himself nonetheless to a site survey of military areas in fortified towns or strongholds, without surveying in detail the outlines of the fortification, these areas being besides exempt from taxation."

37. Boutoulle, Frédéric; Jean-Courret, Ézéchiel; Lavaud, Sandrine, dirs. Atlas historique de Bayonne... 
spatial changes that complicate the identification of common points between the time of the old map and the present day.

\subsection{Drawing up and constructing the documentary record of transmission}

To handle the available data and the need for readers to understand the operations conducted on such and such a type of document led me to summarize them in the form of a "record of transmission", 38 presented in the front matter to each atlas after the short history of the cadastral campaign of the town covered by the volume. The practice in diplomatics is for the record of transmission to identify all evidence of the deed (here the cadastre made up of maps and registers) and to rank it by assigning letters representing its place order in the procedure (original, copies, earlier editions); practice besides intelligibly determines the "useful" and the "useless" evidence, that is, evidence that is and is not used in the editing process. ${ }^{39}$ The composite character of cadastral sources leads to rearrangements being made in the record of transmission. Accordingly it is necessary to include among the evidence the digitized versions of the planimetry insofar as the computerized operations of digitization and then georeferencing (see below) exert constraints such that they can be considered as exemplars in their own right. The nature of the order lettering is also modified by this: the inclusion of digital evidence does not readily fit in with the standardized use of upper case letters (for handwritten manuscripts) and lower case letters (for printed editions), and so it has been chosen to refer to such evidence using lower case letters of the Greek alphabet. Lastly, the multiple sources that can be included in an edition (grid chart, sections and sheets, section statements, matrices) as well as their specific titles lead to the record being presented in several parts, so that readers find it intelligible and accurate (table 1). As many records of transmission must be produced as there are municipal cadastres to edit and as required for the purposes of the study: for the atlas of Mont-de-Marsan, the example below for the small commune of the town is supplemented by the record of transmission for the cadastres of the communes of Saint-Médard-de-Beausse, Nonères, Saint-Jean-d'Août, and Saint-Pierre-du-Mont, each of which includes faubourgs of the agglomeration of the end of the First Empire.

38. Bourgain, Pascale; Vielliard, Françoise, eds. Conseils pour l'édition...: II, 54-72; Guyotjeannin, Olivier; Pycke, Jacques; Tock, Benoît-Michel. Diplomatique médiévale. Turnhout: Brepols, 1993: 402-411.

39. Bourgain, Pascale; Vielliard, Françoise, eds. Conseils pour l'édition...: II, 59: “The term 'useful' describes all preserved copies directly derived from the lost original, or from a lost copy. In contradistinction, and more simply, copies derived from evidence (original or copy) that is preserved besides are declared 'useless'... These terms may be misleading for the uninitiated: they simply mean that a copy is 'used' or is not used for establishing the text, with no value judgement (a 'useless' copy for the editing process is still useful in terms of knowing about the dissemination of a text)." 


\section{Table 1. Record of transmission for the cadastre of the commune of Mont-de-Marsan (code INSEE: 40192), 1811}

Title: Tableau d'Assemblage / du Plan cadastral parcellaire de la Commune de / MONT DE MARSAN / Canton de Montdemarsan / Arrondissement de Montdemarsan. Dépt des Landes / Terminé sur le terrein le 4 février 1811 sous l'Administration / de $M^{r}$ le Comte d'Angosse Préfet I $M^{r}$ Dulyon Maire / et sous la Direction de / $M^{r}$ Galatoire Directeur des Contributions / $M^{r}$ de Digoine Ingénieur Vérificateur / Par M. Brun Géomètre du Cadastre.

Date: Index (4 February 1811) ; cadastral boards (s.d.) ; Status section (s.d.).

Authors: $\mathrm{M}^{\mathrm{r}}$ Galatoire (directeur des Contributions directes), Louis de Digoine (ingénieur vérificateur du département des Landes), $\mathrm{M}^{\mathrm{r}}$ Brun (géomètre du cadastre).

Sections and sheets: $A^{u}, B^{u}$.

Documentary tradition: $\boldsymbol{A}$. Original file of the plan, manuscript, lost $-\boldsymbol{B}$. Field Sheet, manuscript, from $\boldsymbol{A}$, lost exemplary; Status section, manuscript record, lost. $-\boldsymbol{C}$. Copy of the Prefacture of the Department (copy of the plan), manuscript with pen and ink, coloured, from $\boldsymbol{B}, \mathrm{AD} 40,286 \mathrm{~W}$ 192/14 (index), sheets of lost sections, 4 February 1811; Status section, AD40, 3PP 1012, s.d. - D. Copy of the township (copy of the plan), manuscript with pen and ink, coloured, from B, AD40, E Dépôt 192 1G 1/1 et 2, lost index, s.d. ; Status section, lost.

$\alpha$. Digitalized copy, from $C$, AD40_286_W_192_14.tif - $\beta$. Digitalized copy, from $D$, AD40_ EDEPOT_192_1G1_01.tif and AD40_EDEPOT_192_1G1_02.tif, s.d. - $\gamma$. Georeferenced copy, from $\alpha$ and $\beta$, AD40_286_W_192_14_rectif.jpg, AD40_EDEPOT_192_1G1_01_rectif. jpg et AD40_EDEPOT_192_1G1_02_rectif.jpg

Useful copies: from $\boldsymbol{C}$ (Copy and Status section) and $\boldsymbol{D}$ (copy), $\alpha$ (digitalized copy), $\beta$ (digitalized copy) et $\gamma$ (georeferenced copy).

\begin{tabular}{|l|l|l|l|}
\hline Section & Sheet & Author & $\begin{array}{l}\text { Cote } \\
\text { (AD40, preceded by the order letter) }\end{array}$ \\
\hline $\begin{array}{l}\text { A said of } \\
\text { the Church } \\
\text { l'Église }\end{array}$ & 1 & [Brun] & $\begin{array}{l}\text { D. E Dépôt 192, 1G 1/1 } \\
\text { B. E DEPOT_192_1G1_01 }\end{array}$ \\
\hline $\begin{array}{l}\text { B said of the } \\
\text { village }\end{array}$ & 1 & Brun & $\begin{array}{l}\text { D. E Dépôt 192, 1G 1/2 } \\
\text { B. E DEPOT_192_1G1_02 }\end{array}$ \\
\hline
\end{tabular}

The record contains 10 headings broken down into three parts. The first part is made up of information (title, date, authors, and sections and sheets) used for a synthetic analysis (summary). The title of the grid chart is the only item that provides precise references of the communal constituency, the date of the field survey, and the various actors involved in operations. It forms the reference title for the record of transmission because the cadastral plates and registers do 
not necessarily record this information. The "title" heading then develops in full the lettering of the title cartouche (the solidus sign / marks line breaks; spelling, case, and punctuation are unchanged). The field for the date sets out the dates of the end of operations shown on the grid chart, on the cadastral plates, and on the registers (where missing, s.d. stands for undated [sans date]). Next the authors in charge of cadastral operations in the Direct Contributions departments (director, chief surveyor, superintendent and/or verifying engineer) are named; the indications concerning the prefect and mayor in office are not repeated (title cartouche); as the actual authors of the planimetric plates, the field surveyors are named at the end of the table; unfortunately the clerk who drafted the land assessment registers is never named. The lettered description of the sections and the number of sheets ${ }^{40}$ of which they are composed closes this first part.

Then, as is classically done in editing sources, the second part of the table presents the documentary transmission of each evidentiary item listed, coupling the map and registers that form the two parts of each item of evidence. Lost copies that it is certain did exist are of course included in the record. For known exemplars, the short description of each evidentiary item specifies, for the map: the nature of the planimetric document, its physical appearance, ${ }^{41}$ its connection with earlier items of evidence in the case of expedited copies, its archive references (deposition and catalogue number), and its date; for the register providing the metadata used (see below): the register typology, its archive references (deposition and catalogue number), and its date. Handwritten evidentiary items are included with upper case letters indicating the order and digital testimonials are indicated by lower case letters of the Greek alphabet. To overcome the difficulties in interpreting this complex line of descent, the third part of the table indicates briefly which copies are useful and then more specifically presents the planimetric sheets (section designations by letter and name, sheet number of each section, surveyor, archive reference, and reference to the documentary tradition). The size of the commune and therefore the number of sections and sheets comprising it mean that this part is very variable in length in different instances: from just two lines for the small commune of Mont-de-Marsan to several tens of lines for Bordeaux.

\subsection{Exposition of the editing protocol}

When the assembly of the various items of documentary evidence is complete, the editor's work proper begins. Here again, whether with texts or cadastres, digital applications that make up the tool box of any researcher facilitate and complicate the project to the extent that they can be used to put together different deliverables.

40. Section letter followed, in brackets, by the number of sheets if more than 1 , the indication "u» (superscript) if the section comprises as single (unique) sheet.

41. So as not to burden the description of each item of evidence, the cadastral plate dimensions are not included because they are systematically in grand aigle format (in fact, both $65 \times 95 \mathrm{~cm}$ and $75 \times 105 \mathrm{~cm}$ formats are noted under this name). 
"In what form should one's work be delivered to users?"42 The printed edition of a corpus of medieval texts and the electronic edition of the same corpus do not involve the same tools or the same conceptual models, they are not presented in the same way, not preserved in the same way, they are not open to the same uses, and they do not provide the same possibilities for questioning. ${ }^{43}$ The same goes for the editing of a cadastre, the printed version of which is limited to the map, without any real possibility of publishing all the metadata extracted from the registers, but that can, however, be consulted in an electronic version. This version is still not yet an electronic edition when it amounts only to a geodatabase reserved for a few users and that must be the subject of webmapping to ensure the dissemination of spatial data over the Internet. The collection of French atlases is for the time being limited to the printed edition of the cadastral reference maps that yield only a part of the geographical information; this is a sizeable limitation with respect to the scale of consultation (limited to 1:2500 for the historical map), the print window (limited to the format of plotters, that is, map windows far smaller than the zone studied and mapped in the course of research), and the nature of the data that can be consulted (only those recorded on the map, which is infinitely less than the metadata recorded). The development of electronic editions is a major challenge for the French collection which does not wish to discontinue the current form of the printed book and map but which is heading down this road thanks to the experiments with the collections of the German, Italian, and British and Irish atlases. ${ }^{44}$ Here we shall not discuss the pros and cons of printed or electronic forms but of all the operations that the editing strategy implies.

The geographical information of cadastral documentation associates the objects mapped (parcels and the water courses and highways around them) and the data in the registers relating to them (parcel number, place name, proprietor's name, type of land, class, area, income). This dual nature of geographical information is particularly suited to the structure of topology software ${ }^{45}$ that combines geometric data (polygons, lines, points) and semantic data (attribute tables) within a defined geographical space. CAD (computer-assisted drawing) applications which are still widely used for producing maps —and which were used for several earlier

42. Bourgain, Pascale; Vielliard, Françoise, eds. Conseils pour l'édition...: II, 75.

43. See the considerable contribution of the works of InterPARES (<http://elec.enc.sorbonne.fr/ interpares $2 />$ ).

44. Reflections and projects developed within the International Commission for the History of Towns (Atlas Working Group) with the collection editors, namely Daniel Strake for the Deutscher Historischer Städteatlas; Francesca Bocchi and Rosa Smurra for the Atlante storico delle città italiane; Keith Lilley for the British Historic Towns Atlas, and Sarah Gearty and Jacinta Prunty for the Irish Historic Towns Atlas.

45. These software packages are too commonly described as GIS (Geographic Information Systems); now, a GIS is the outcome of a methodological approach designed to "update historical phenomena in terms of geographical, thematic and temporal spaces with respect to a given issue and a starting hypothesis" (Pirot, Françoise. De la modélisation de l'Information Géographique à la création des données géospatiales", Représenter la ville, Sandrine Lavaud, Burghart Schmidt, dirs. Bordeaux: Ausonius éditions, 2009: 309-343, citation 317). The different levels of modelling (spatial, conceptual, logical and physical data modelling) are not involved in the editing approach. So here we cannot speak of GIS but simply of the use of topology software for cadastral editing. 
volumes in the atlas collection- are unsuitable for the establishment of largescale cartographical frames of reference because they do not provide the alignment tools, vectorization tools, or metadata recording tools provided by computerized mapping applications. Beyond the chosen topological software, ${ }^{46}$ editors must be attentive to the nature of the digital document serving as the basis of their work (evidentiary items noted $\alpha$ in the record of transmission; see illustration 8 ). The transformations that digitized maps must support entail the use of flat digitizations and not photographs to the extent that the camera lens produces sizeable optical deformations of the picture. The raster image, made up of rows and columns of pixels, must be of high resolution, ${ }^{47}$ delivered in a low compression format (tiff is to be preferred to jpeg), and in a suitable colorimetric mode for the software environment.$^{48}$ Researchers seldom master this initial datum because they usually work with cadastral maps made available to them free-of-charge as digitized by the departmental archives; they must, though, make allowance for it because the standard of digitization has repercussions for the stages in the work to be performed.

The production of a geohistorical frame of reference based on digitized maps includes the operations of georeferencing and of geometrical (vectorization) and semantic (recording of attributes) data construction; each step is a highly specific task that requires a stage of verification/correction/validation. The order of operations may differ with the protocol laid down: the protocol is often confined to works that are not readily accessible (unpublished dissertations) or that gloss over this part of the "spadework" when they are published. A very well-known exception to this observation applies to the work of the ALPAGE group, made up of a score of specialists (historians, geographers, computer scientists) whose activity reports and summary book available online ${ }^{49}$ provide all the details of the "methods of reconstructing the Vasserot map" which was nothing other than an edition of the "urban cadastre", albeit with no registers. The appraisal of the topographic quality of the source maps, the development of protocols for the various operations, the experimentation with potential operational sequences, and the quality control of output were all guiding principles behind this exemplary undertaking. Not all projects have the advantage of such an environment and scholars when set to

\footnotetext{
46. All the operations for the atlas collection were performed with ArcGIS ${ }^{\odot}$. However, there is a wide range of free software packages (GRASS, G-GIS, QGIS, gvGIS, OpenJump, uDig, KOSMO, SAGA, MapWindow), extensions, and complementary tools that can be integrated with them. Editors must nonetheless be careful to choose applications enabling them to manage information easily in raster and vector form together with their attributes. Software packages differ above all in terms of their ergonomics. 47. The selected resolution must allow for the scale of the plate to be digitized. A 300 dpi resolution of a 1:500 or a 1:2000 scale map affects pixel quality in the digital image.

48. To the best of my knowledge, topology software packages have an RGB default colorimetric mode (even if it provides conversions to other modes) whereas computer graphics and editing software packages work with CMYB as their default mode. This affects the sometimes surprising results obtained by automatic colorimetric mode transformation from one application to another.

49. Noizet, Hélène; Bove, Boris; Costa, Laurent, dirs. Paris de parcelles en pixels...; resources and cartographic platform access on <http://alpage.huma-num.fr/fr/>.
} 
work editing cadastral sources are often isolated and at something of a loss when faced with this "labour of love". Yet, whatever the size of the team, what matters most is knowing, sharing, and complying with the approaches developed; for the atlases, the cartographic frames of reference were produced by from one to four researchers working to the same set of specifications.

The editorial advice I now wish to offer is dependent on the overall strategy envisaged; a few words must be said about this strategy before detailing the stages. The three operations (georeferencing, vectorization, recording of attribute data) and discussed after in that order, may be arranged differently in the operational sequence, without considering the inspection and validation steps specific to each of them. Starting from the scanned maps, two processing sequences can be contemplated: ${ }^{50}$ the first is to georeference the raster plans and then to vectorize the geometrical data and lastly to enter the metadata; the second is to vectorize the geometric data and then georeference them ${ }^{51}$ before finally entering the attributes of each object. In these options, the georeferencing and vectorization stages are interchangeable and, in the end, do not produce very marked differences in the results. The flexibility provided by topology software could lead to the attributes being entered at some other time than at the end. While technically feasible this does not seem viable to me. It seems to me that this operation should be carried out once the cartographic reference frame has been developed inasmuch as the entry, object by object, of all the semantic data we wish to record forms a stage of inspection and validation of the planimetry in addition to those checks made previously for the same purpose. Moreover, performing this task blind, by referring to the cadastral registers alone, without comparing them with the objects mapped, would be an aberration and would mean mistakes made when drawing up the cadastre (match between maps and registers) or when vectorizing objects would go unnoticed.

Georeferencing is the operation that consists in placing the objects mapped on the digitized maps within a spatial reference system so as to be able to localize them using geographical coordinates $(x, y)$ in a cartographical projection system. ${ }^{52}$ In practice, this action involves comparing the objects on the old planimetric sheets

\footnotetext{
50. Noizet, Hélène; Bove, Boris; Costa, Laurent, dirs. Paris de parcelles en pixels...: 20: the two processing chains were implemented in the ALPAGE project. These parallel approaches provided an opportunity to evaluate the deviations between two possible types of vectorization, one in which the different layers of objects were generated manually and the other built up by developing a vector object extraction algorithm for automatically generating geometric data.

51. We speak more specifically of spatial fitting of vector data whereas georeferencing is more specifically associated with raster data.

52. Chareille, Pascal; Bouju, Alain; Bethe, Anne-Laure; Noizet, Hélène. "Le géoréférencement des plans Vasserot: méthodes, déformations, interprétations", Paris de parcelles en pixels. Analyse géomatique de l'espace parisien médiéval et moderne, Hélène Noizet, Boris Bove, Laurent Costa, Laurent, dirs. Paris: Presses universitaires de Vincennes, Comité d'histoire de la Ville de Paris, 2013: 38; Rouet, Paul. “Dictionnaire des termes techniques", Paris de parcelles en pixels. Analyse géomatique de l'espace parisien médiéval et moderne, Hélène Noizet, Boris Bove, Laurent Costa, Laurent, dirs. Paris: Presses universitaires de Vincennes, Comité d'histoire de la Ville de Paris, 2013: 306.
} 
with those on the present-day georeferenced digital map so as to target common points between the two maps. The links between each of these "homologous" points are used in visualizing the cadastral maps realigned on the reference map. Such points can be identified with varying degrees of ease, depending on the spatial changes that have been made between the dates of the source map and the reference map; it is sometimes useful therefore to have maps of intermediate dates for aligning sheets.

Because there are as many choices as there are possible situations, I shall settle here for synthesizing a few useful tips for conducting this work on the scale of each extract map as on the scale of each composite map. The most reliable control points are often those located on the parcels, because the built environment is subject to more rapid transformation. However, the points fronting the roadways and the shared boundaries benefit from the enduring character of the parcels that the points that might be located on built features toward the rear of the plot do not share. The points must be sufficient in number ${ }^{53}$ and distributed as evenly as possible over the area of each sheet because their number and distribution affect the type of transformations that can be made. These transformations are mathematical formulas that change the coordinates of the source points (located on old maps) into coordinates of target points on the projected presentday map. These transformations deform to varying degrees the ratios of areas, angles, and alignments of the objects mapped depending on the complexity of the equations they use, by stretching/contraction/distortion of the digitized maps. For the Paris project, the georeferencing of the plates surveyed for each block was done with the affine (also termed type 1) transformation because it preserves the geometric characteristics of the objects drawn on the cadastral maps quite well. ${ }^{54}$ This choice cannot be readily reconciled for cadastral plates made up of several blocks because "this global and homogenous transformation cannot be used to correct local deformations"; ${ }^{55}$ while valid for a single sheet, the choice is not viable for the composite maps of all the sheets of a cadastre (unless the sheets are cut up by blocks so as to do the georeferencing by blocks, which would be fastidious and has not been tested on cadastres to my knowledge). Accordingly, for the atlases, we opted for the type 2 (spline) transformations that provide more flexibility. However, since no transformation is ideal, the operator must take care to record all the tables of links made in positioning the check points and record the type of transformation selected so as to be able to adjust the alignment of one sheet as the georeferencing of the adjoining sheets proceeds. The undertaking is conducted sheet by sheet and sometimes even in several stages when a sheet includes developments of the parcel sector, making one wonder where to begin.

\footnotetext{
53. Rouet, Paul. “Dictionnaire...": $307:$ " 3 to 8 or 10 points, beyond which the gains in precision are generally tiny."

54. Chareille, Pascal; Bouju, Alain; Bethe, Anne-Laure; Noizet, Hélène, dirs. “Le géoréférencement des plans Vasserot...": 45 .

55. Chareille, Pascal; Bouju, Alain; Bethe, Anne-Laure; Noizet, Hélène, dirs. “Le géoréférencement des plans Vasserot...": 45 .
} 
On the scale of a commune, or of several communes forming an urban area, it seems logical to me to georeference the sheets by working outwards from the centre towards the edges so that the inevitable alignment errors will be more evenly spread. Moreover, the sheets should be georeferenced with respect to a pattern of adjacency by following an overall spiral, which is an effective way of checking the fit of the seams between sheets.

Georeferencing operations are delicate but it is necessary to estimate the quality of them. They are conducted somewhat empirically and their validation involves several criteria beginning with the quality of the matches between adjacent sheets. Such seams are usually based on hydrography and the road network, for which the proper spacing must therefore be preserved. Quite often these joins rely on parcel alignments which must then be made to match as closely as can be between neighbouring sheets. A more impartial method is the comparison of the RMS (root mean square) indicator, an "algorithm designed to minimize the distance and the position of each homologous point" 56 on the source image and the present-day georeferenced map. Émilie Cavanna's work has shown how this indicator reveals correlations between computed RMS values and certain factors inherent in the context in which the cadastre is produced, beginning with the variable topographic constraints of the areas mapped. ${ }^{57}$ Experiments on the towns of Aquitaine support these conclusions meaning that the indicator can be used as a "measure of reliability, [with which] to evaluate the informative limits of one document compared with another and finally to weight its interpretation". ${ }^{58}$ So far as possible, the RMS values of the different sheets must be homogeneous if it is taken that the survey team was confronted with the same topographical constraints and implemented the same surveying methods. RMS values are calculated from residual errors for each homologous point, and so it need only be checked that the deviations between these residuals are not way out ${ }^{59}$ between points on the same sheet and between the different sheets that have been aligned.

Raster map resolution is dependent on the number of dots per inch or dpi selected when the maps are digitized. This matrix of pixels arranged in rows and columns has a limited display resolution. Vectorization consists in transforming raster objects into vector objects, which are a mathematical representation of the objects located in space according to the coordinates of a geographical system. The resolution of vector objects is therefore unlimited even if their topographical precision is dependent on the quality of the survey. This stage may be performed

56. Rouet, Paul. “Dictionnaire...": 307.

57. Cavanna, Émilie. “Cartes et plans anciens: des images de l'espace du passé à déchiffrer (Moyen Âge, époque moderne)", Les images: regards sur les sociétés. Paris: Éditions de la Sorbonne, 2011 : <http://books. openedition.org/psorbonne/5749> (Consulted $16^{\text {th }}$ January 2019).

58. Cavanna, Émilie. "Cartes et plans anciens...".

59. The residuals recorded in the link table vary with the type of transformation. It seems logical not to accept in the same table points whose residuals are of the order of $1 / 10$ th and points whose residuals are of the order of 10 or 100 for example. The RMS value depends, however, on the accuracy of the chosen check points, which are often easier to identify in the urban fabric (a little less subject to change) than in rural parts that have been overrun by the town since the time of the old cadastre. 
either manually by the operator, who must then interpret the nature of the lines and correctly position the vector (which must then be positioned in the middle of the thickness — or "weight" - of the lines forming the raster object), or automatically using shape recognition algorithms designed on the basis of the source image and the research project. ${ }^{60}$ Despite constant technological advances, there is still no recognition software for automating this work on any type of cadastral maps whatsoever; although the feature codes used on them were standardized under the First Empire, disparities in drawing are still too complex to be grasped by artificial intelligence, even if swift developments in this area are hoped for. For the time being, most vectorization is still done manually, making this a very time-consuming stage.

There are three methods of manual vectorization. To comply most closely with the draughting of the maps (and therefore the orientation and alignment of objects), the creation of vector spatial entities one after another is inoperative because the operator's hand and eye, however, accurate and keen, fail to comply in this way with the isocline of the alignments. Constructing parcels with the same alignment on the raster map one after another is not viable. This "constructivist" approach, which is still used too often, must be abandoned for the more analytical vectorizations of the other two methods. The first is to begin by drawing the largest topographic units, as polygons, complying with the isocline of the alignments (blocks and portions of blocks), and then to cut up these huge polygons along the other lines of the plan of the parcels still taking care to comply with the unbroken alignments of several parcels. This is the method used for the frames of reference in the atlases. The second, and more intricate methods in terms of data management, is to vectorize not by polygon but by line, again complying with the alignments. Polygons can then be created automatically using the properties of network topology. ${ }^{61}$ However, this method involves vectorizing the lines by type of object, otherwise sorting by layers of objects generated becomes complicated.

The organization of a directory of data categorizing objects by layers according to their nature is paramount. Manual vectorization of the plan of parcels and of the built environment is a lengthy, not to say comparatively thankless task. If it is to be homogeneous, the work must be done to the same standards and, so far as can be, on a constant scale (for sheets surveyed at 1:2500 for example, try to work around 1:500). Besides, the creation of the other layers (hydrography, roadways, non-built land, communal boundaries, sections and sheets) is much faster because it is facilitated by the tracing tools, the scripting tools for mapping and data management included in topology software (for example, the layer of non-built objects can be created very quickly by subtracting the built layer from the parcel

60. Raveaux, Romain; Burie, Jean-Chirstophe; Ogier, Jean-Marc. “La vectorisation automatisée des plans Vasserot", Paris de parcelles en pixels. Analyse géomatique de l'espace parisien médiéval et moderne, Hélène Noizet, Boris Bove, Laurent Costa, Laurent, dirs. Paris: Presses universitaires de Vincennes, Comité d'histoire de la Ville de Paris, 2013: 53-65; Rouet, Paul. “Dictionnaire...": 308.

61. Network topology consists, for a set of lines, in forming a graph, whether planar or non planar, made up of arcs and nodes from which layers of polygonal, polyline or point objects are extracted. 
plan layer, etc.). Whether automatic or manual, vectorization proceeds by choices that only the operator is able to make to palliate the constraints that digitization has been unable to settle, because they are attributable to the preservation of source documents (folds in cadastral maps, of which that associated with their binding is not the least, gaps in the maps because of holes and tears, stains, etc.). The reconstruction of lines that have to be made to palliate the gaps take account of the parcel-based logic of the old cadastre that is sometimes found on the present-day cadastre. Whatever the modifications made, the content should be indicated in a specific field of the attribute table that records, after a fashion, the critical apparatus of the editing choices.

The printed or electronic format of the edition may also force users to make choices. The frequent mistakes with the survey of complex edifices such as the château of Pau have already been noted. The 1828 cadastre of Périgueux poses further problems. The block of Saint-Front cathedral must have proved difficult to survey because the edifice was still at that time entangled in the remains of the old monastery and encroached upon by private buildings. To whom or to what should these "mistakes" be ascribed? The surveyors may have been a little offhand with the château at Pau —but as it was a non-taxable public building, the error was therefore of no consequence for the collection of taxes- but not in the Périgueux case because the errors in the survey of the cathedral had consequences for the adjoining built property at least part of which was taxable. Should the document then be edited as it stood or should it be corrected using contemporary sources? I ask this false question deliberately because it all depends on the project assigned and any answer may be acceptable provided one clearly sets out what one is doing and provided that the various versions of the work are preserved. In the Atlas historique de Périgueux, the Puy-Saint-Front sector is highly complex because of the long period of settlement since the palaeo-Christian era. The paper version of the historical map in the atlas could not present tangled, confused lines that would verge on making the map unreadable. I therefore opted to correct the block in question and to present it as corrected on the printed map. The geodatabase preserves all of the information produced (uncorrected cadastre, corrected cadastre, historical layers; see illustration 9).

Checking the quality of vectorization is a key stage that determines the spatial analyses to be made from the frame of reference. Software can be used to set out rules of surface topology "associated with the properties of juxtaposition, superimposition, inclusion, and exclusion of surface type objects with each other", ${ }^{2}$ so as to check the conformity of each layer and of the layers with one another.

The recording of semantic data is the final stage in editing ahead of the development of feature codes. The parcel numbers (from 1 to $\mathrm{n}$ for each section) can be input sheet after sheet. It is a further validation stage of the vectorization process confirming that all the parcels have been properly identified (no duplicates,

62. Rouet, Paul. “Dictionnaire...": 308. 
no orphan parcels) and that spatially distant entities that are grouped under the same number are correctly combined. It is advisable to compose a single identifier per parcel so as to avoid any confusion between identical numbers. For this purpose, the following information may be strung together to form the identifier: name of the commune, date of the map, section, sheet number, parcel number (e.g. PERIGUEUX_1828_Du_0425 is the identifier for the parcel of Saint-Front cathedral). The content of the cadastral registers may then be entered in part or in full depending on the geohistorical study project. For atlases, the socio-economic data (owner's names, income, etc.) have not been entered, and attention has focused instead on the landscape (place names and land use of the parcel plan layer; street names for the street plan). The data of the attribute tables were recorded for the parcel plan layer and then imported automatically to the other layers by spatial jointure. Here again, the "landscape language" recorded in the registers must be strictly adhered to; a specific field in the attribute table may be produced to generalize the similar types of land and in the context of the collection to produce feature codes common to all volumes. The highly standardized character of the terms employed, arranged by property pricing classes, produces a picture of a fiscal and not an actual landscape. For the cadastral map backgrounds of the atlas to be legible, I was forced to simplify the taxonomy of the built properties; the terms used to describe the type of non-built property were usually easier to adapt to the feature codes in use in the collection. Like the source planimetry sheets, the built environment was not depicted in its lexical and functional diversity but only in terms of its footprint, contrary to the arable, wooded or uncultivated land for which the feature codes transcribe an idea of the fiscal landscape.

Now that the time has come to end this contribution, I would like to speak out for and defend its being more reflective and militant than rule-making in character. The sometimes polemical tone is meant only to alert the academic community around the source-space about the possible options for constructing geohistorical frames of reference on the basis of old cadastres, about what can and cannot be expected of these evidentiary items because of their intrinsic limits, and about the acceptable manipulations we impose on them for extrinsic purposes. What I have had to say is in no way revolutionary but it follows in the wake of a debate begun by so many predecessors about the construction and use to be made of source materials. There is nothing prescriptive about the proposals and advice; I am very much aware of the limitations of this approach, both in terms of my own inability to pinpoint alone all of the problems to be contemplated and to identify the right solutions. I do express the hope, though, that all those of use who are confronted with the challenge, through the prism of various disciplines and issues, might agree to develop together editorial advice and principles that are every bit as respectable as those that have been patiently developed for texts.

The recourse to and adaptations of diplomatics and literary genetics revive approaches that have often been perceived as purely technical operations, confining their authors to an ancillary role whereas they do or should be doing a full editing job. Like the works of the Paris group, this editing ambition can be 
accomplished only by the combined action of several specialists (geomaticians, computer scientists, historians, geographers, etc.) because, with all the good will in the world, the historian-cartographer can only tinker about in his own little corner of the room. The epistemological ambition of this essay is not to try to transform critical editing into genetic editing. ${ }^{63}$ While it is important to trace the genesis of a cadastre in order to understand the documentation produced to make it, it is only one context-based approach to an operational campaign. The objective of critical editing is to establish a cadastre in the same way as people work to establish a text, not to "make readable and intelligible the stage(s) of its genesis or the entire process that gave birth to it". The wide documentary corpus of a cadastre makes it impossible to edit all of the textual and planimetric items, that are both interconnected and heterogeneous and that drive its production through to its actual implementation in collecting taxes. And while the digital humanities appear "capable of solving the problems that almost always arise with the mass and complexity of traces... it would be naive to imagine that technologies born of computer science do not in their turn and in other regards give rise to as many problems as they solve".$^{64}$ Overcoming these constraints probably involves making a new epistemological leap and changing the disciplines that construct frames of references from sources and data into "a cross-cutting science of processes... [that] takes as its field of study a universe of clues that are as numerous as they are diverse, a sort of world archive" ${ }^{65}$

63. See the reflections and distinctions of De Biasi, Pierre-Marc. Génétique des textes...: 151-154.

64. De Biasi, Pierre-Marc. Génétique des textes...: 154.

65. De Biasi, Pierre-Marc. Génétique des textes...: 280-281. 


\section{Appendix}

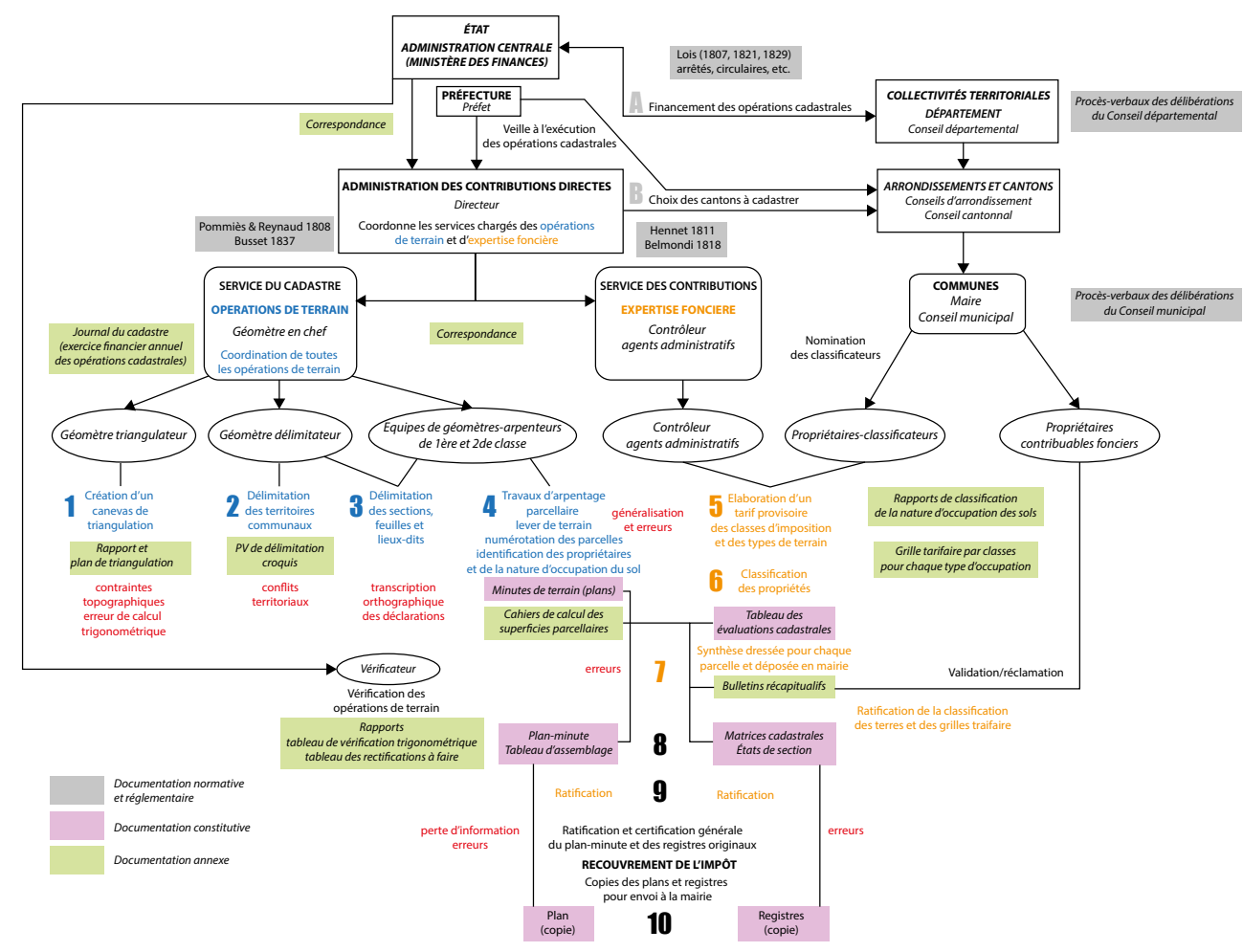

ILLUSTRATION 1. THE ACTORS, SEQUENCE OF OPERATIONS, AND TYPE OF DOCUMENTS INVOLVED IN THE OLD CADASTRE. 

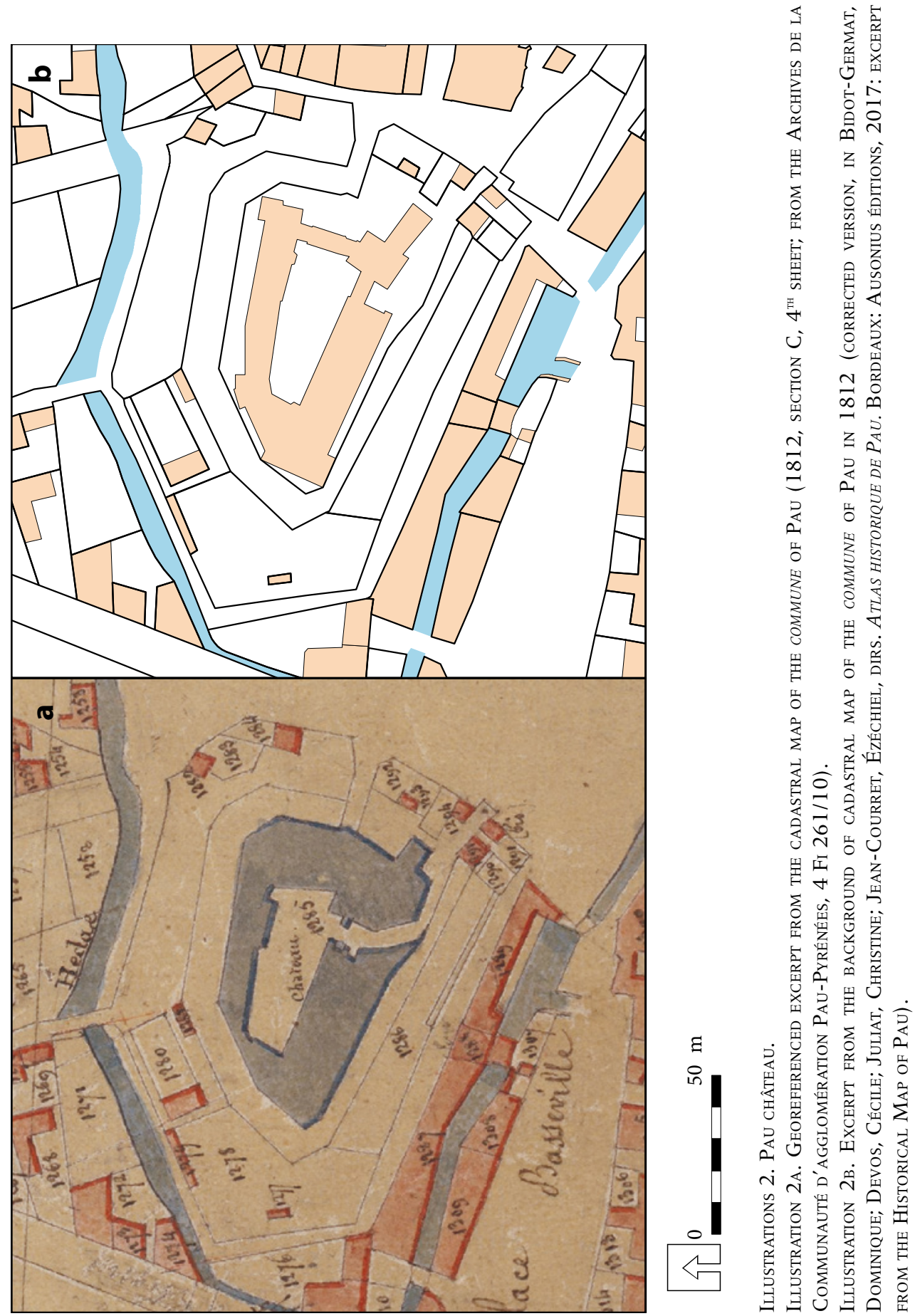

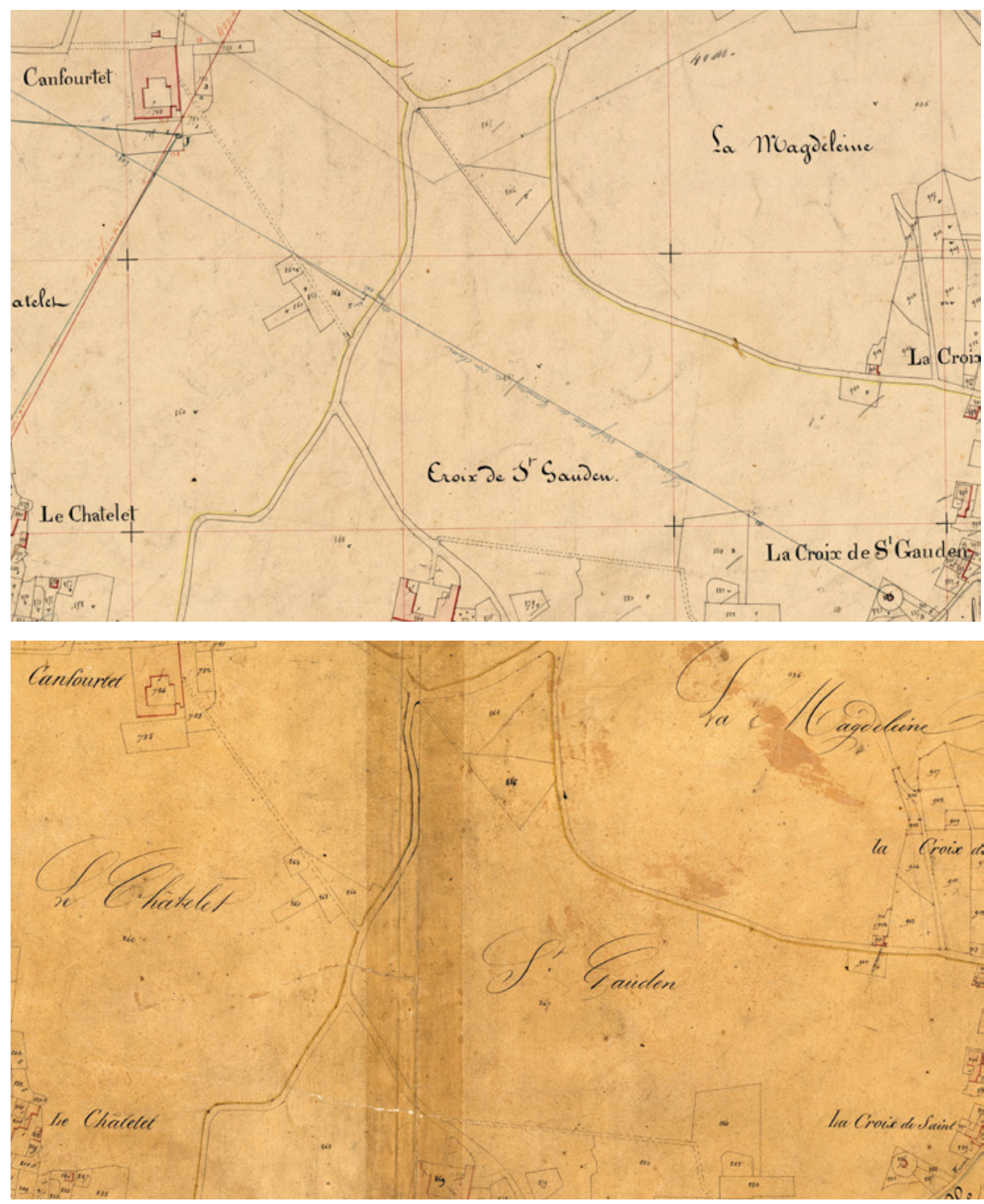

Illustrations. 3. Cadastral map of the commune of Saint-Emilion (1845).

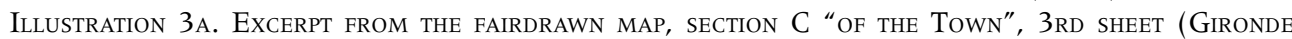
DEPARTMENTAL ARCHIVES, 3P 394/26).

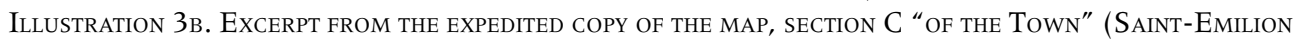
COMMUNAL ARCHIVES, NOT INDEXED). 

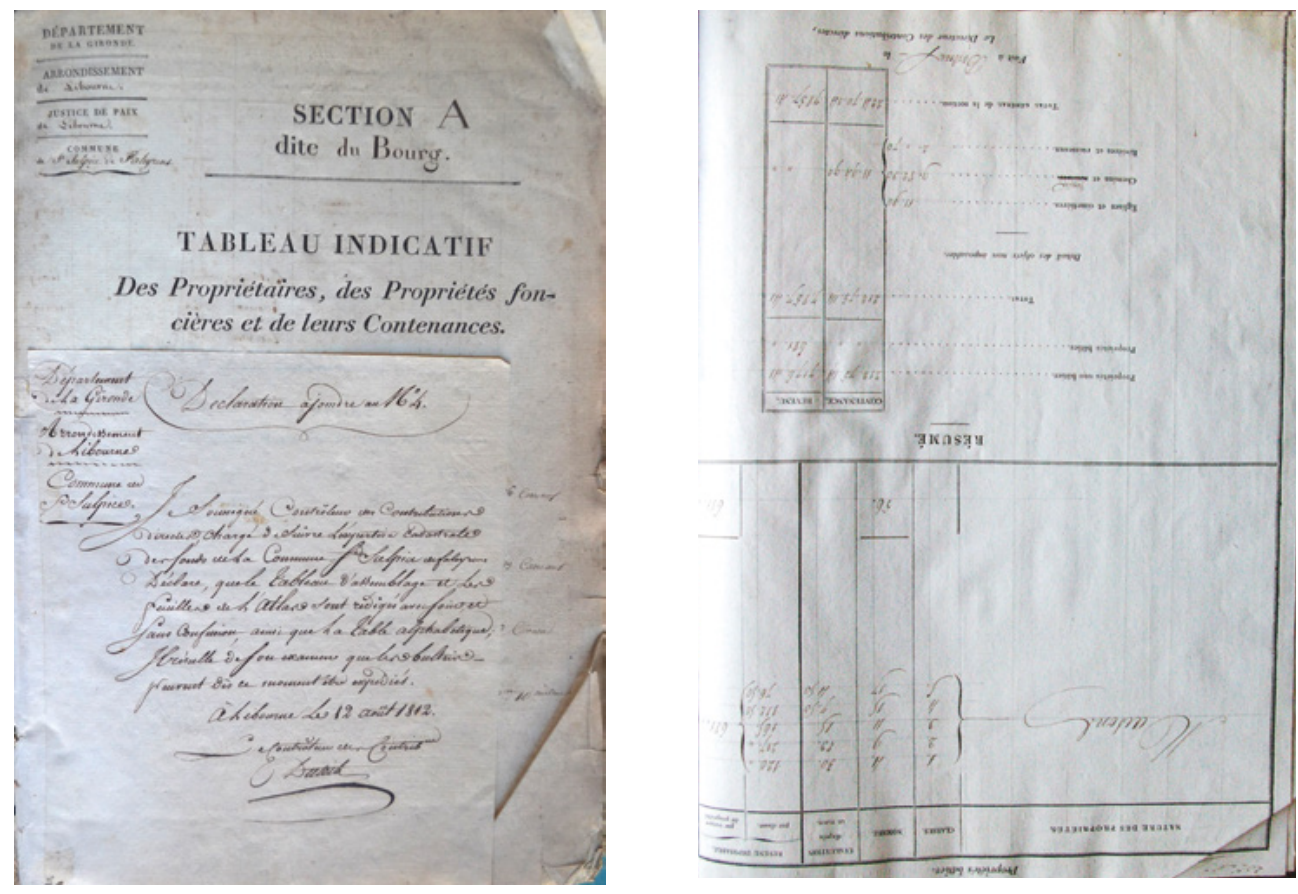

Illustrations 4. Registers of the cadastre of the commune de Saint-Sulpice-de-Faleyrens (1812). Illustration 4A. Table of proprietors RATIFIEd by inspector Duteil (CADAstral matrix, Gironde DEPARTMENTAL ARCHIVES, NOT INDEXED, PICTURE BY EZÉCHIEL JEAN-CouRRET). TRANSCRIPTION AND TRANSLATION: JE SOUSSIGNÉ CONTRÔLEUR DES CONTRIBUTIONS DIRECTES, CHARGÉ DE SUIVRE L'EXPERTISE CADASTRALE DES FONDS

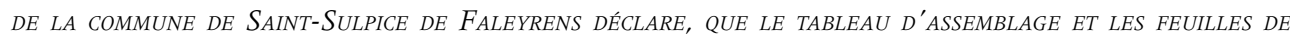
L'ATLAS SONT RÉDIGÉES AVEC SOIN ET SANS CONFUSION, AINSI QUE LA TABLE ALPHABÉTIQUE; IL RÉSULTE DE SON EXAMEN QUE BULLETINS PEUVENT DĖS CE MOMENT ÊTRE EXPÉDIÉS. À LIBOURNE LE 12 AOÛT 1812. LE CONTRÔLEUR des Contribut[ions] dutell (“I, the undersigned, Superintendent of Direct Contributions, tasked with

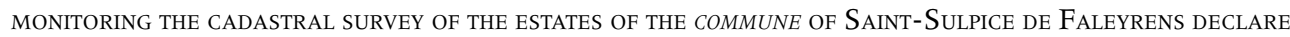
THAT THE GRID CHART AND SHEETS OF THE ATLAS ARE DRAUGHTED WITH CARE AND UNCONFUSEDLY, TOGETHER WITH THE ALPHABETICAL TABLE; AS A RESULT OF EXAMINATION OF IT, SUMMARY RECORDS MAY BE EXPEDITED AS OF now. Done at Libourne on this $12^{\text {Th }}$ DAY of August 1812. Superintendent of Contribut[ions] DuteiL").

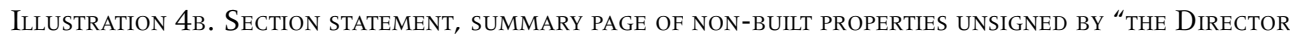
of Direct Contributions" (Saint-Sulpice-de-Faleyrens communal archives, not indeXed, picture by EzéCHIEL JEAN-Courret). 


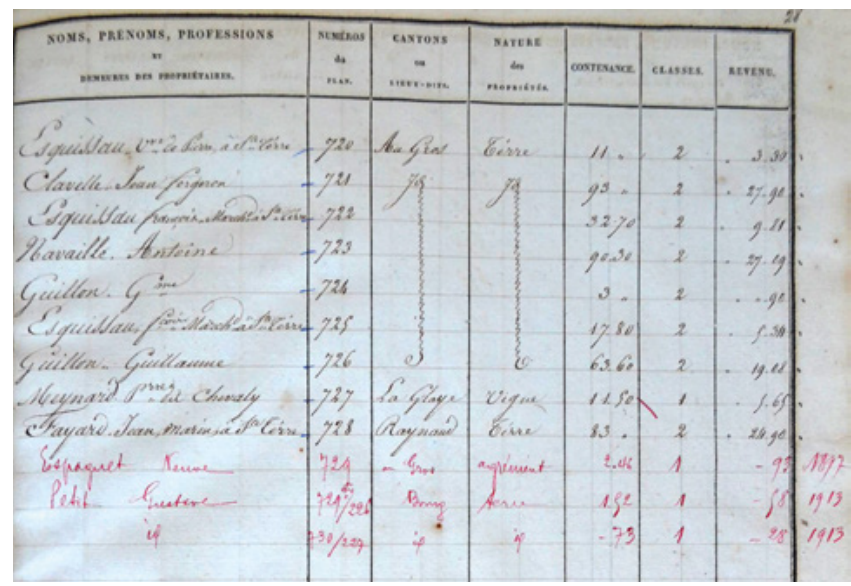

Illustration. 5. Section statement of the cadastre of the commune of Saint-Pey-d'Armens (1814, Saint-Pey-d'Armens COMMUNAL ARCHIVES, NOT INDEXED, FOL. 28, SHEEt E. JEAN-CouRRET). NOTICE THREE NEW PARCEL NUMBERS ADDED IN RED INK AND IN OTHER HANDWRITING AND DATED 1897 AND 1913, THAT IS, ALMOST A CENTURY AFTER THE CADASTRE WAS FIRST DRAWN UP.

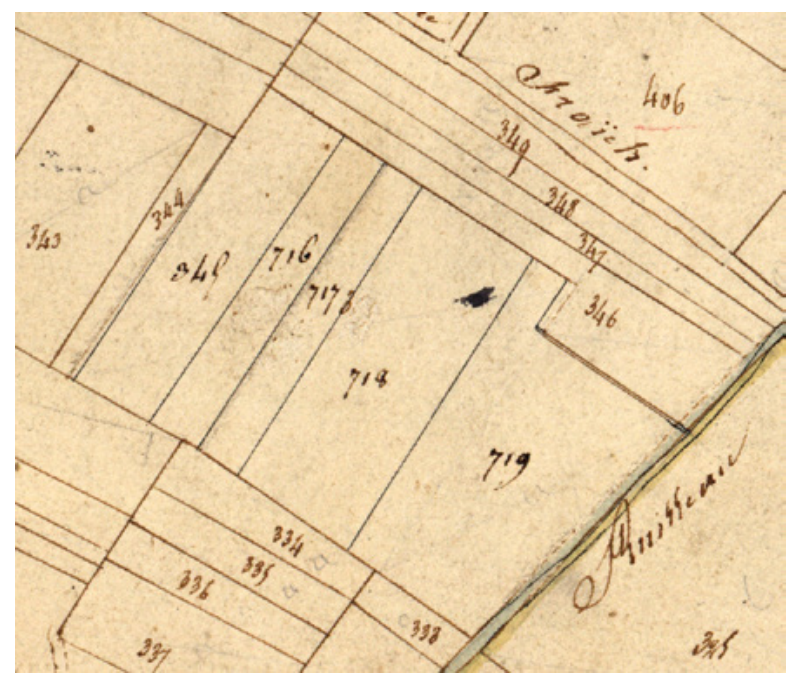

ILLUSTRATION 6A. EXCERPT FROM THE CADASTRAL MAP OF the COMmune OF SAINT-Pey-d'Armens (1814, Gironde departmental archives, 3P459/2, Section A “the Market TOWN", $1^{\text {sT }}$ SHEET). THE SHADES OF INK (BROWN FOR THE ORIGINAL LINEWORK, BLACK FOR ADDITIONS) REVEAL THAT PARCEL 345 WAS DIVIDED. BETWEEN PARCEL 344 AND THE STREAM, THE OLD PARCEL 345 (THE 3 MARKED TO THE RIGHT OF PARCEL 717 IS STILL VISIBLE) WAS DIVIDED INTO FIVE PARCELS (NEW PARCEL 345 AND PARCELS 716 то 719$)$. 


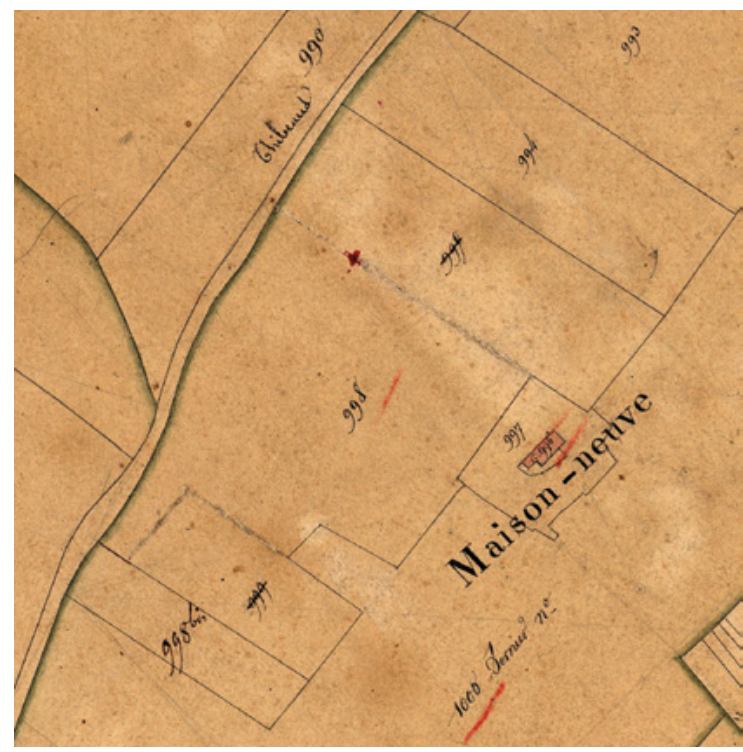

ILLUSTRATION 6B. EXCERPT FROM THE CADASTRAL MAP OF THE COMMUNE OF Saint-Etienne-de-Lisse (1819, Gironde DEPARTMENTAL ARCHIVES, 3P396/3, SECTION $\mathrm{B}^{\mathrm{u}}$ "Le Thibeaud"). Notice the crossingsOUT OF PARCEL NUMBER 999 AND 995 AND THE SCRATCHING OUT OF THE PARCEL BOUNDARIES: PARCELS 995 AND 999 WERE MERGED WITH PARCEL 998 SOMETIME AFTER THE MAP WAS DRAWN UP.

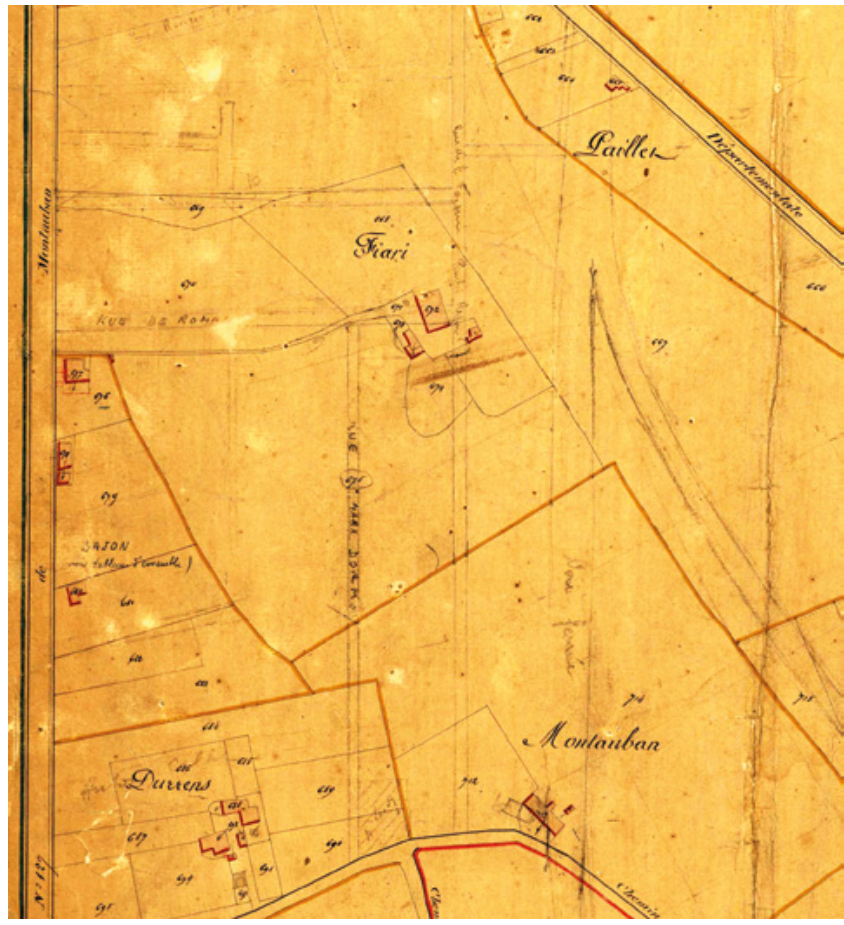

Illustration 6C. EXCEPT FROM THE CADASTRAL MAP OF THE COMMUNE OF Agen (1845, LotET-GARONNE DEPARTMENTAL ARCHIVES, 3P21/22, SECTION B "Le SAint-Esprit", 3RD SheEt). Notice, IN LEAD PENCIL, THE ROUTE of the RaILWAY IN the Montauban SECTOR AND THE STREETS OF A PLANNED HOUSING DEVELOPMENT IN THE FIARI SECTOR. 


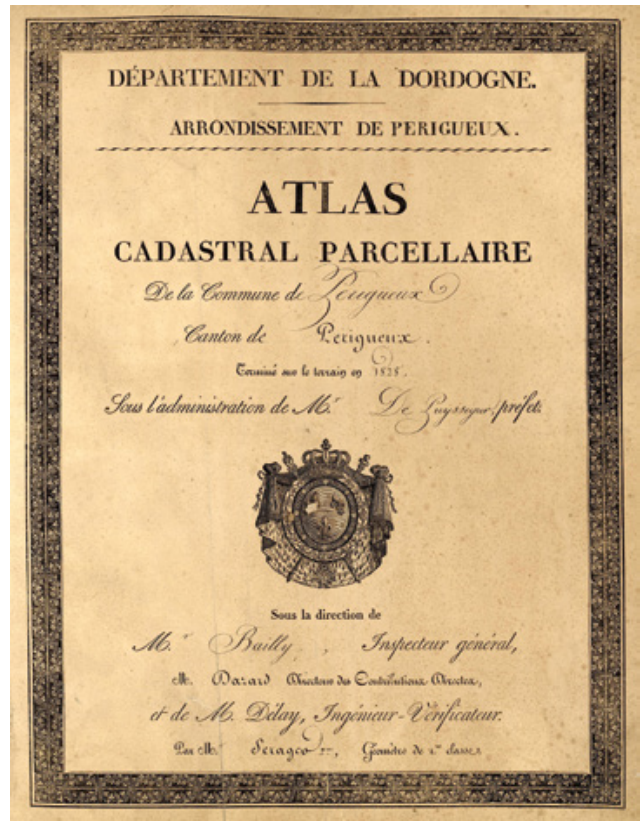

Illustration 7. Presentation cartouche of the Atlas of parcel plans of Périgueux (Dordogne DEPARTMENTAl ARCHIVES, E DÉPôt 10013/1).

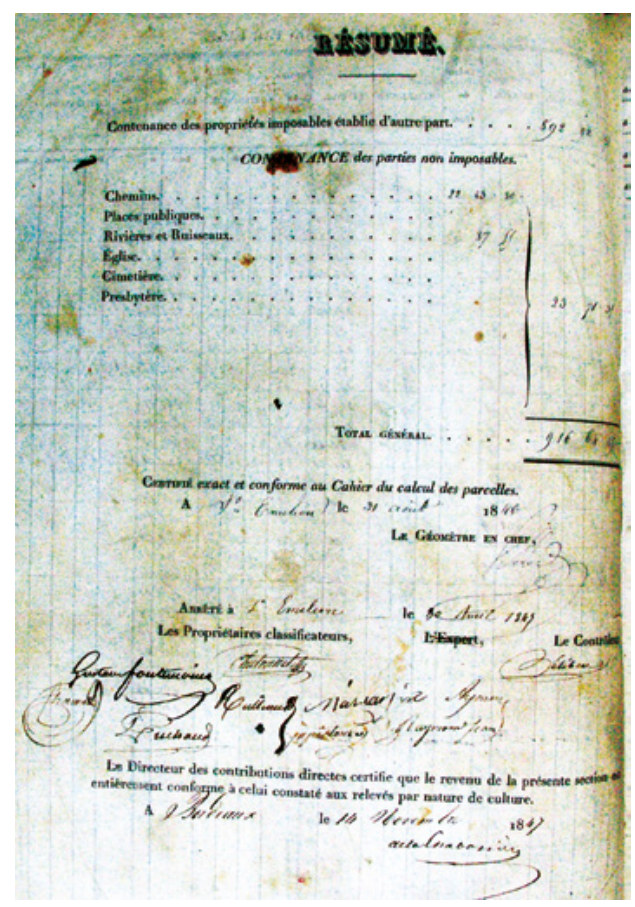

Illustration 8. Section Statement of the CADAstre of the COMMUNE OF SAINT-EMILION, SUMMARY PAGE (14 November 1847; Gironde Departmental ARCHIVES, NOT INDEXED). 


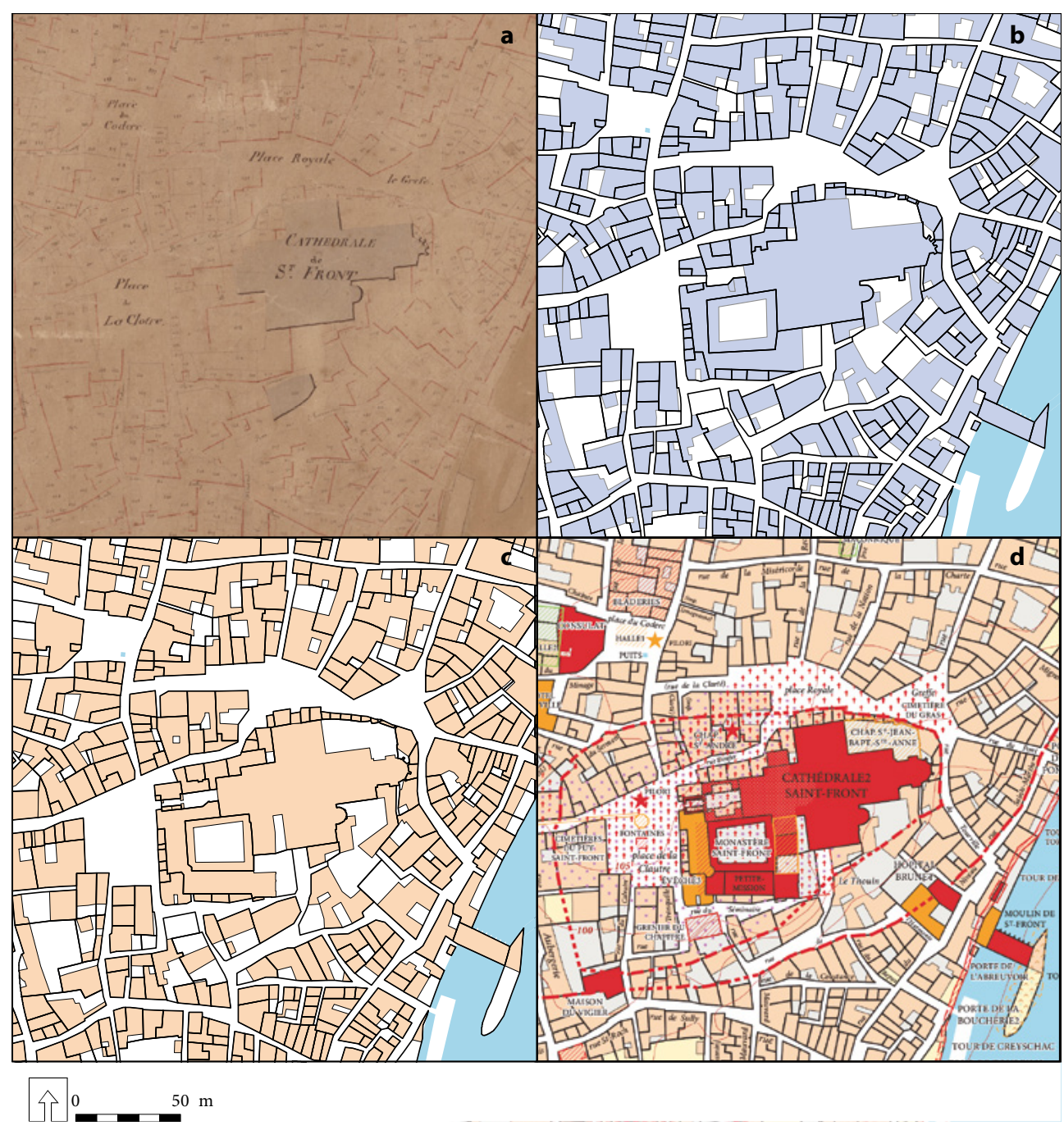

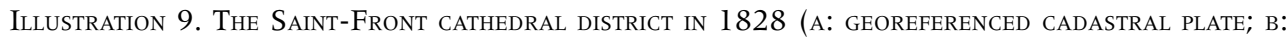
VECTOR EDITION TRUE TO THE GEOREFERENCED PLATE; C: CORRECTED VECTOR EDITION; D: MAP EXTRACTED FROM: Gaillard, Hervé; Mousset, Hélène; Jean-Courret, Ézéchiel, dirs. Atlas historique de PérigueuX...). THE MOST BLATANT DifFERENCES ARE WITH THE CATHEDRAL CHEVET, THE CLOISTER, AND THE BUILDings ADJOINING THE CLOISTER. 